\title{
Review of the marine isopod crustacean genus Hansenium Serov and Wilson, 1995 (Asellota: Stenetriidae) from tropical Australia and Papua New Guinea, with description of a new genus
}

\author{
NIEL L. BRUCE ${ }^{1} \&$ CHAD BUXTON \\ Museum of Tropical Queensland, Queensland Museum, 70-102 Flinders Street, Townsville, Australia 4810; School of Marine and \\ Tropical Biology, James Cook University; and Department of Zoology, University of Johannesburg, South Africa \\ ${ }^{\text {I}}$ Corresponding author. E-mail: niel.bruce@qm.qld.gov.au
}

\section{Table of contents}

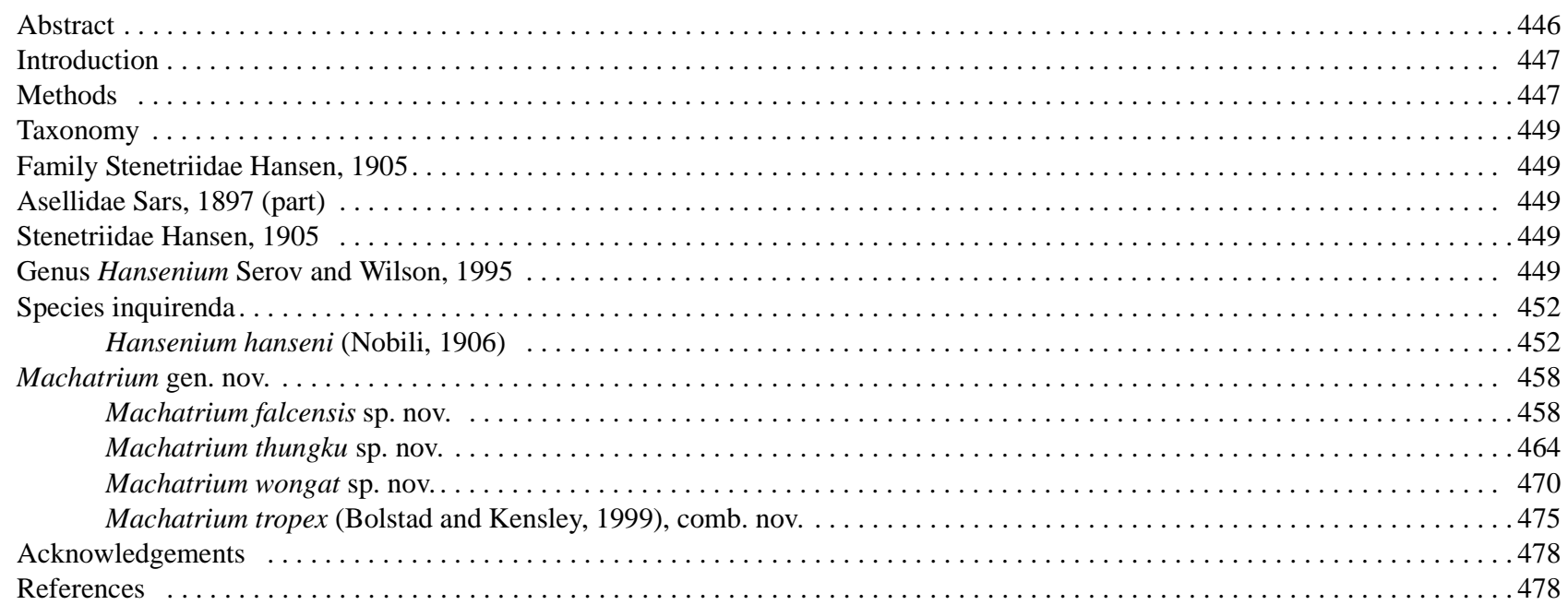

\begin{abstract}
The genus Hansenium is revised and a new diagnosis presented. A neotype is designated for the type species Hansenium hanseni (Müller, 1991), and the genus is restricted to the type species and Hansenium remocarpus Kensley and Schotte, 2002. Machatrium gen. nov. and the following species are described: Machatrium falcensis sp. nov. (type species), Machatrium thungku sp. nov. from Lizard Island, Great Barrier Reef; Machatrium wongat sp. nov. from Madang, Papua New Guinea, Machatrium tropex (Bolstad and Kensley, 1999), comb. nov. also from Madang, Papua New Guinea; a further five species are transferred from Hansenium to Machatrium gen. nov. The remaining species of Hansenium are retained as incertae sedis in their existing combination (11 species), reallocated to other genera (1 species) or regarded as species inquirenda (3 species). The principal differentiating characters of Hansenium, Machatrium gen. nov. and Stenetrium Haswell, 1881, are the pseudorostrum being short and trapezoid or long and anteriorly narrowed, morphology of the male pereopod 1, notably the shape of the propodus inferior margin, presence or absence of a process on the inferodistal margin of the merus and carpus; and the apex of the appendix masculina being acute or blunt, with or without a concavity and with or without terminal setae.
\end{abstract}

Key words: Asellota, Stenetriidae, Hansenium, Machatrium, new species, Australia, Great Barrier Reef, Papua New Guinea, coral reefs 


\section{Introduction}

The first species of what would be the family Stenetriidae Hansen 1905 were described from eastern Australia when Haswell (1881) described two species of Stenetrium from Port Jackson, Sydney. To date, a total of 83 species of Stenetriidae have been described worldwide and 18 of these are currently placed within Hansenium Serov and Wilson, 1995 (Schotte et al. 2011). Serov and Wilson (1995) provided the only comprehensive generic review of the Stenetriidae, rediagnosing the family and distributing the species across eight genera, including three new genera. Lexcenium Serov and Wilson, 1999 brings the current number of genera within Stenetriidae to nine.

Stenetriids occur worldwide in shallow temperate to tropical environments and occasionally in the deep-sea (Kensley 1984; Kensley and Schotte 2002; Müller 1991a, b; Schultz 1982). Recent sampling under the CReefs program (2008-2010) has identified eight genera on Australian tropical reefs including the new genus described herein. Only two stenetriid genera have previously been recorded from Australia (Poore et al. 2002) despite stenetriids being ubiquitous on coral reefs, and not one species has been described from tropical Australian coasts. This contribution presents a restrictive diagnosis to Hansenium, basing the concept on the type species Hansenium hanseni (Nobili, 1906), which is redescribed, and a neotype is designated from Müller's (1991a) specimens. The remaining species are considered as incertae sedis or species inquirenda or allocated to other genera, including the new genus described herein.

\section{Methods}

Substrate samples were collected using SCUBA during the Lizard Island component of the CReefs Australia project (2008-2010; see http://www.aims.gov.au/creefs). Samples were collected from the reefs around Lizard Island, adjacent islands and adjacent outer barrier reefs (Fig 1). Samples were taken from 1-30 metres depth. Substrata were gathered into either $350 \mu \mathrm{m}$ mesh bags or lidded 20-litre plastic bucket(s) during the dive. Each sample was washed with approximately $30 \%$ freshwater and left to sit for a maximum of 30 minutes, then washed with a 30\% ethanol-70\% freshwater mixture, for a maximum of 30 minutes. The substrata were gently shaken and broken up to dislodge specimens and then removed by hand. Sandy substrata were gently stirred but left in the buckets. The solutions were rinsed through a $250 \mu \mathrm{m}$ soft-mesh net and specimens either identified immediately to ordinal level and preserved in cooled 95\% ethanol or bulk preserved in 95\% ethanol and placed in a refrigerator depending on time constraints. Every effort was made to preserve specimens while alive to reduce appendage loss and quality for future DNA studies.

Descriptions were generated using a DELTA database (Coleman et al. 2010; Dallwitz et al. 2000). Whole animals were drawn using a Leica MZ125 dissecting microscope and appendages were drawn using a Leica DM2500 compound microscope equipped with differential interference contrast and a camera lucida. Dissected appendages were temporarily mounted on slides using an $85 \%$ lactic acid solution, lightly stained with lignin pink.

'Additional material' refers to specimens identified as belonging to a species but were not used in preparing the description.

Digital Inking. Pencil illustrations were scanned and electronically inked using a graphics tablet (Wacom Intuos4) and GIMP, Inkscape and Adobe Illustrator CS5. A dorsal view of the pleotelson for each species was drawn with the aspect specifically positioned to allow for descriptive measurements, though not necessarily included in the published figures. In habitus drawings, specimen curvature of these animals often distorts the true length of the pleotelson.

Terminology. Setal terminology is based on terms used by Garm (2004) and Watling (1989) where possible; some morphological terms were taken from Serov and Wilson (1995) to retain descriptive consistency. Orientation terminology follows Bruce (2009). Unless otherwise stated, setae are simple.

Pereopod morphology. The male pereopod 1 is critical in defining both genera and species. A set of standard measurements has been developed that encompasses the diverse morphology shown by the propodus and carpus of pereopod 1 in Hansenium and related genera. The terms and measurement positions used to describe the pereopod 1 are described below and shown in Figure 2.

Length-width of article is measured medially from distal margin to proximal margin, excluding processes; width measured at the widest point; where processes are present the measurement is taken anterior to where the setae start along the margins. 

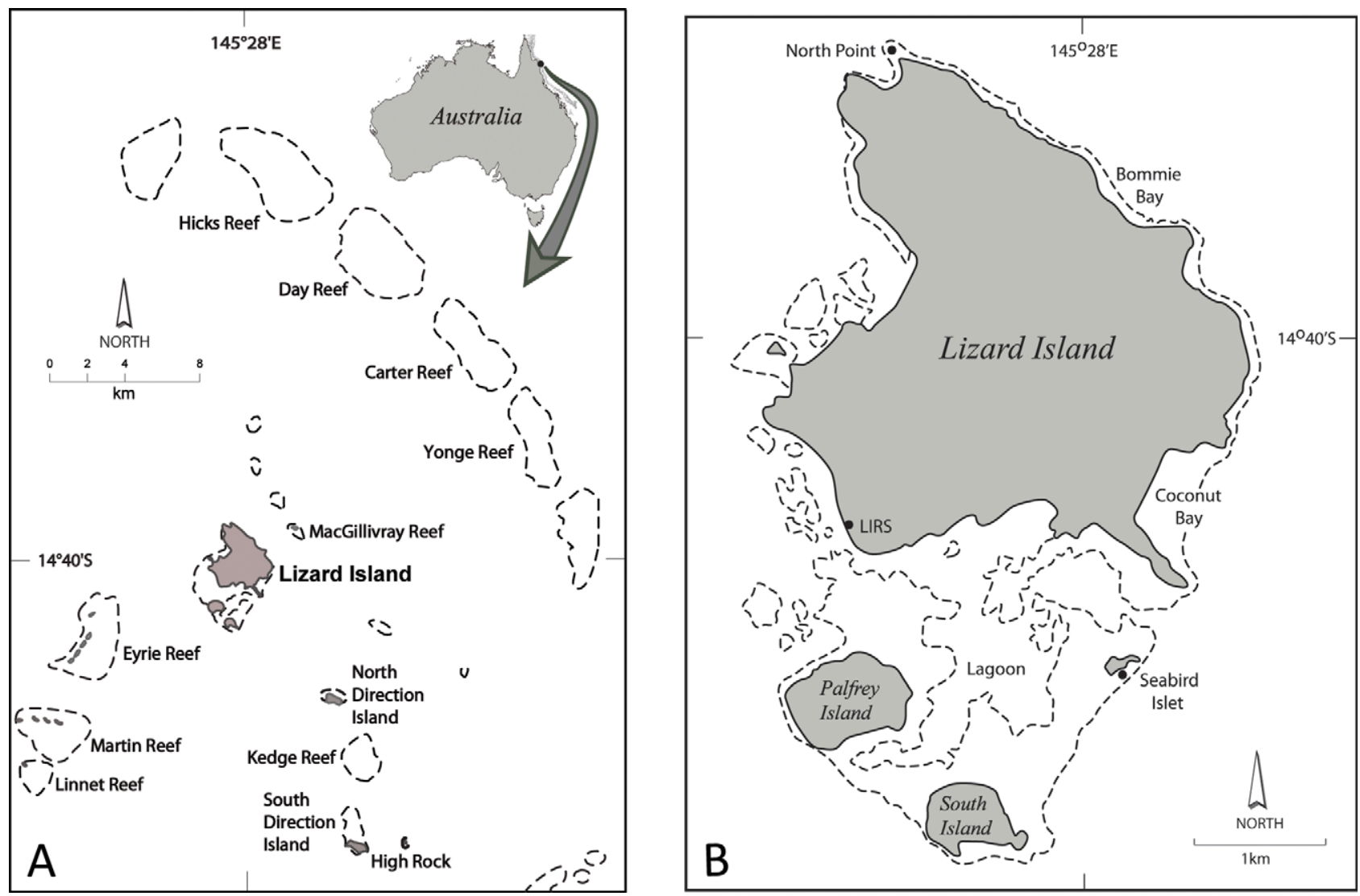

FIGURE 1. Location of collecting sites. A, Lizard Island and neighbouring reefs on the Great Barrier Reef, Queensland, Australia. B, Lizard Island group, showing principal collecting locations and Lizard Island Research Station (LIRS) marked with solid circles.

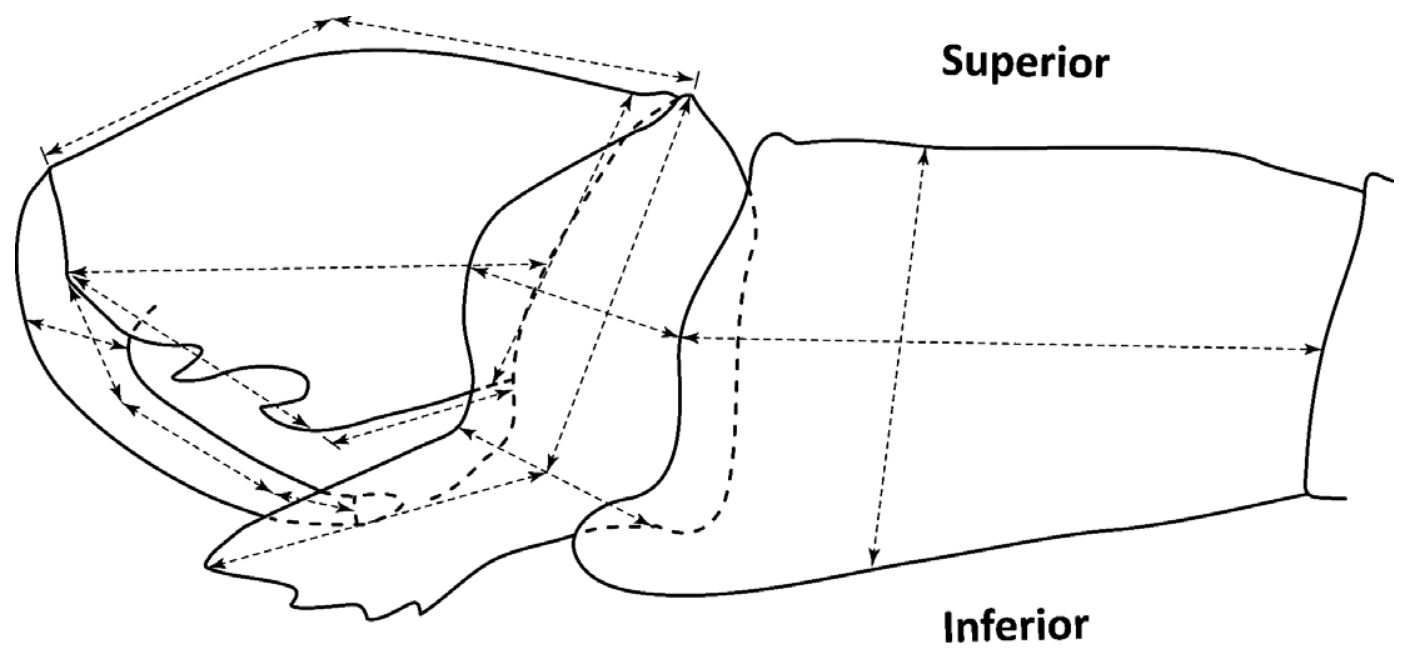

FIGURE 2. Measurements used on male pereopod 1, illustrated with Hansenium hanseni.

Carpus inferior process length is measured against carpus proximal margin width.

Propodus inferior margin measured from the proximal margin to the base of the inferodistal tooth-seta, point of inflection or propodal process (if present).

Propodal palm length is measured from the inferodistal spine, point of inflection or propodal process (if present) to the mesial point of the dactylus-propodus articulation.

Palm orientation is described in relation to the propodal longitudinal axis, as primarily oblique (e.g. Hansenium) or truncate (e.g. Stenetrium, Machatrium gen. nov.). 
Dactylus length is measured from unguis proximal margin to medial point of dactylus-propodus articulation; proportion measured is length/proximal width.

Propodal 'robustness'. The term 'robust' is used in relation to the thickness of the inferior part of the article. In Stenetrium and Machatrium gen. nov. the propodus has a thickened and rounded superior margin that, in section, narrows medially and is flattened towards the inferior margin. In Hansenium, the flattening out of the inferior side is absent, giving the article a greater thickness and more 'robust' appearance.

Propodal palm. The term 'palm' is widely used in descriptions of pereopod 1, but has rarely been defined. The presence or absence of an oblique or transverse terminal palm is a defining character for some stenetriid genera. The palm is here defined as the strongly inflected distal part of the inferior margin of the pereopod 1 propodus that runs from the point of dactylus-propodus articulation to a inferomesial angle usually defined by a prominent RS or spine (Fig 2); the dactylus usually opposes the palm. The palm may also be described as reduced and in some cases absent. A reduced palm is here defined by the palm width being less than half the dactylus length.

\section{Abbreviations}

MTQ-Museum of Tropical Queensland, Townsville, Queensland Museum; SEM—scanning electron microscope; SMF-Forschungsinstitut Senckenberg, Frankfurt; RS-robust seta/e; GBR—Great Barrier Reef.

\section{Taxonomy}

Family Stenetriidae Hansen, 1905

\section{Asellidae Sars, 1897 (part)}

\section{Stenetriidae Hansen, 1905}

\section{Genus Hansenium Serov and Wilson, 1995}

Hansenium Serov and Wilson, 1995: 72.—Bolstad and Kensley 1999: 164.—Kensley and Schotte 2002: 1443.—Martin, Heard and Wetzer 2003: 975.

Type species. Stenetrium hanseni Nobili, 1906; by original designation (Serov \& Wilson 1995).

Species included. Hansenium hanseni (type species), Hansenium remocarpus Kensley and Schotte, 2002.

Species retained in combination with Hansenium but here regarded as incertae sedis, species inquirenda, or transferred to other extant genera are discussed in the 'Remarks' section below. Hansenium tropex Bolstad and Kensley, 1999 is here transferred to Machatrium gen. nov. and Stenetrium bowmani Kensley, 1984 (pseudorostrum rounded; merus and carpus without evident lobes or process; propodus with transverse palm) is returned to the original combination.

Table 1 lists all species in the original and new combinations.

Diagnosis (male). Cephalon lateral and antennal spines acute, sub-equal in length. Pseudorostrum quadrate, wider than long. Eyes large (more than 12 ommatidia), reniform. Male pereopod 1 merus subquadrate, inferodistal process small and rounded; carpus inferodistal process blade-like, serrate; propodus robust, propodal palm oblique with 2 teeth, without a terminal seta or spine; dactylus length 1.0-1.5 times propodal palm length. Male pleopod 2 appendix masculina distally broad, terminally blunt without setae, lateral margin with or without a distal proximally directed spine.

Description (male). Body dorsal surface smooth or sparsely setose, widest at pereonite 1; pereonite 1 length greater than 1.5 times pereonite 2 length; pereonites 2-4 lateral margins convex, anteriorly acute. Pleotelson subequal to width; lateral margins smooth, sub-parallel, posterolateral spines prominent, margin posterior to spines rounded with weak apical point; dorsal surface smooth or sparsely setose. 
TABLE 1. Species of Hansenium Serov and Wilson 1995 and Machatrium gen. nov. mentioned in this work (alphabetical by species).

\begin{tabular}{|c|c|c|}
\hline Original combination & Type locality & Current combination \\
\hline Hansenium aldabrae Kensley and Schotte, 2002 & Aldabra Atoll, Seychelles & Machatrium \\
\hline Stenetrium antillense Hansen, 1905 & West Indies & Incertae sedis \\
\hline Stenetrium bowmani Kensley, 1984 & Belize & Stenetrium \\
\hline Stenetrium caicosense Kensley and Heard, 1991 & Turks and Caicos Island & Incertae sedis \\
\hline Stenetrium chiltoni Stebbing, 1905 & Sri Lanka & Species inquirenda \\
\hline Stenetrium dodo Müller, 1991 & Réunion Island & Incertae sedis \\
\hline Stenetrium echiurum Nobili, 1906 & Tuamotu Islands & Incertae sedis \\
\hline Stenetrium entale Nordenstam, 1946 & Tapeteuea, Gilbert Islands & Incertae sedis \\
\hline Hansenium expansum Kensley and Schotte, 2002 & Nosy Bé, Madagascar & Incertae sedis \\
\hline Machatrium falcensis sp. nov. & Lizard Island, GBR & Present work \\
\hline Stenetrium gilbertense Nordenstam, 1946 & Ararai, Gilbert Islands & Species inquirenda \\
\hline Stenetrium hanseni Nobili, 1906 & Tuamotu Islands, French Polynesia & Hansenium \\
\hline Stenetrium medipacificum Miller, 1941 & Hanauma Bay, Hawaii & Species inquirenda \\
\hline Stenetrium monodi Nordenstam, 1946 & Gulf of Suez & Machatrium \\
\hline Stenetrium occidentale Hansen, 1905 & St. Thomas, West Indies & Incertae sedis \\
\hline Hansenium remocarpus Kensley and Schotte, 2002 & Mahé Island, Seychelles & Hansenium \\
\hline Stenetrium spathulicarpus Kensley, 1984 & Belize & Machatrium \\
\hline Stenetrium stebbingi Richardson, 1902 & Bermuda & Incertae sedis \\
\hline Hansenium thomasi Bolstad and Kensley, 1999 & Madang, Papua New Guinea & Incertae sedis \\
\hline Machatrium thungku sp. nov. & Lizard Island, GBR & Present work \\
\hline Hansenium tropex Bolstad and Kensley, 1999 & Madang, Papua New Guinea & Machatrium \\
\hline Stenetrium wilsoni Müller, 1991 & Moorea, Society Islands & Incertae sedis \\
\hline Machatrium wongat sp. nov. & Madang, Papua New Guinea & Present work \\
\hline Stenetrium zanzabaricum Kensley and Schotte, 2002 & Murogo Reef, Zanzibar, Tanzania & Machatrium \\
\hline
\end{tabular}

Cephalon lateral margins smooth. Antennae length equal or longer than total body length, article 1 lateral spine absent.

Pereopod 1 basis superior margin with regularly spaced setae along length, superior submarginal ridge without setae; carpus inferodistal margin with well-developed process; propodus with convex superior margin, propodal palm with teeth along palm margin.

Pleopod 1 protopod rectangular, lateral margin setae present or absent; rami lateral margins evenly convex. Pleopod 2 protopod longer than wide, distal apex sharply pointed; appendix masculina lateral margin groove absent, mediodistal margin hardened. Pleopod 5 distal apex with 3-5 plumose setae.

Female. Generally similar to male but for primary sexual characters in the pleopods and dimorphism of pereopod 1. Pereopod 1 in females is smaller, with a simple sub-chelate propodus and less setose.

Remarks. Serov and Wilson (1995), when establishing the genus Hansenium, acknowledged that a number of characters remained variable in Stenetrium, including rostral shape, going on to say that 'we suspect the genus may yet be further divided as the species are better illustrated'. In addition, the thirteen species included in Hansenium presented a great diversity in the male pereopod 1 morphology, some of which did not conform with the genus diagnosis. Consequently, there has been uncertainty as to what characters unambiguously define Hansenium and also what characters distinguish Hansenium from Stenetrium. All subsequent accounts of the genus (Bolstad \& Kensley 1999; Kensley \& Schotte 2002; Martin et al. 2003) have had difficulties in generic placement of new species, regarding the boundaries between Stenetrium and Hansenium as being unclear.

Serov and Wilson (1995) designated Stenetrium hanseni Nobili, 1906 as the type species for the genus Hansenium, a species for which there is no type material. The diagnosis presented by Serov and Wilson (1995) 
appeared to be based, in part, on Nobili's (1907) few simple figures but all illustrations accompanying their diagnosis were taken from species other than the type species. Bolstad and Kensley (1999) and Kensley and Schotte (2002) both offered new diagnoses to the genus, but on the basis of contained species rather than the type species. Here the genus is again diagnosed, but on the basis of the type species. Although Nobili's illustrations and description are brief (in the extreme), they correspond totally with the description given by Müller (1991a). Furthermore, we have not observed any similar species in the extensive material that we have examined for the genus. Nobili (1906) gave no indication as to where his type material might be housed. Some of Nobili's decapod crustacean specimens are held at the Museo Regionale di Scienze Naturali in Torino, but there is no evidence that any of Nobili's isopod type material is in existence. Several enquiries concerning Nobili's isopod type material have been unsuccessful in locating the specimens. A neotype is therefore designated from Müller's (1991a) specimens, the only existing material for the species, in order to stabilise the generic concept and use of the name Hansenium.

In their diagnoses to the genera of Stenetriidae, Serov and Wilson (1995) use the term rostrum, although genera are figured with a rostrum (e.g. Stenetrium and Stenobermuda (figs 1A and 2E), with a pseudorostrum (e.g. Hansenium, fig. 1E) or without either (e.g. Mizothenar, fig 2A). Several descriptions (e.g. Bolstad \& Kensley 1999; Kensley \& Heard 1991; Kensley and Schotte 2002; Nordenstam 1946) and our own examination of freshly collected material from the CReefs expeditions, show clearly the presence of a pseudorostrum. A SEM taken by Bolstad and Kensley (1999) of Hansenium thomasi shows this morphology clearly.

All species of Hansenium have a short, trapezoid pseudorostrum that is approximately twice as wide as long, while Stenetrium appears to have a broad-based, distally narrowly rounded rostrum or pseudorostrum, the lateral margins of which converge anteriorly and, in several of the species that we have examined, is serrate. The illustrations given by Serov and Wilson (1995) appear to show that there is a rostrum, although the illustration of the Stenetrium armatum Serov and Wilson, 1995 female (fig. 4E) has a fine line drawn across the rostrum base, suggestive of a pseudorostrum. In contrast, Hansen (1905), Kensley (1980), Kensley and Schotte (2002), Nicholls (1929) and Schultz (1982) all illustrate what appears to be a pseudorostrum. All species of Stenetrium collected from Ningaloo reef possess an anteriorly rounded pseudorostrum (personal observation). At present, whether Stenetrium has a rostrum or pseudorostrum remains unclear. We consider that the presence (Stenetrium) or absence (e.g. Hansenium, Machatrium gen. nov.) of a broad-based, anteriorly rounded rostrum or pseudorostrum is a further distinguishing generic character.

The revised concept for Hansenium includes only those species with a trapezoid pseudorostrum, reniform eyes, male pereopod 1 carpus with a well-developed and serrate inferodistal process, and lacking setae on the apex of the appendix masculina. This diagnosis restricts the genus to two species. The remaining species are assigned to the new genus described herein (three species and three new species), regarded as incertae cedis, species inquirenda or assigned to Stenetrium.

Distribution. Hansenium is currently only known from tropical Indo-West Pacific coral reefs.

\section{Hansenium, incertae sedis}

The species listed here are retained in combination with Hansenium, but excluded from the genus sensu strictu as they either lack the diagnostic characters of Hansenium and Machatrium gen. nov., or possess unique characters that preclude their inclusion in other genera. Further undescribed species of these groups are present in CReefs material and other collections. Some of these groups of species, particularly when considered in conjunction with the male pleopod 2 morphology, potentially warrant new genera:

'entale group'-male pereopod 1 without superior meral process; carpus inferodistal margin with ventrally directed, terminally acute process; inferodistal margin of merus with distinct (short to long) blade; propodus inferior margin with large, acute process; dactylus elongate, longer than propodus. Hansenium entale (Nordenstam, 1946); Hansenium thomasi Bolstad and Kensley, 1999 and Stenetrium echiurum Nobili, 1906; two species present on the Great Barrier Reef.

'stebbingi group' - male pereopod 1 carpus inferior margin with anteriorly directed acute process; propodus inferior margin concave, lacking distinct palm, terminating in small lobe. Hansenium stebbingi Richardson, 1902; Hansenium antillense Hansen, 1905 and Hansenium occidentale Hansen, 1905. are regarded as junior synonyms of H. stebbingi (Menzies \& Kruczynski 1983; Kensley 1984). 
Hansenium wilsoni Müller, 1991a-male pereopod 1 with very large carpal process encompassing the propodus and extending beyond the distal margin of the propodus, the propodus articulating within the mesial surface of the carpal process rather than 'end to end'; pereopod palm oblique. Hansenium wilsoni.

Hansenium caicoense Kensley \& Heard, 1991-male pereopod 1 with prominent, acute and anteriorly directed inferodistal meral process; propodus elongate, weakly inflected, oblique palm with spine at point of inflection.

Hansenium expansum Kensley and Schotte, 2002-shows few affinities to any other species or group of species; male pereopod 1 has a short semi-circular carpal process, propodus with large round lobe.

Hansenium dodo Müller, 1991b — shows little affinity to any other species or group of species; male pereopod 1 carpus with short process; propodal palm oblique with terminal tooth.

\section{Species inquirenda}

Hansenium chiltoni (Stebbing, 1905)—male not known; rostrum (or pseudorostrum) rounded; antennal spine on article 1. Later records of this species are misidentifications such as that of Monod (1933), which was later named H. monodi (Nordenstam, 1946).

Hansenium medipacificum (Miller, 1941)—male not known; pseudorostrum trapezoid.

Hansenium gilbertense (Nordenstam, 1946) — male not known; pseudorostrum trapezoid; pereopod 1 similar to that of females of Machatrium gen. nov.

\section{Hansenium hanseni (Nobili, 1906)}

(Figures 3-6)

Stenetrium Hanseni Nobili, 1906: 266.-1907: 414, Pl. 3, fig. 3.

Stenetrium hanseni.—Nierstrasz 1941: 281.—Müller 1991a: 57, fig. 21-37.—Miller 1941: 311.—Serov and Wilson, 1995: 81. Hansenium hanseni.-Serov and Wilson 1995: 72.

Type locality: Viatape, Bora Bora, French Polynesia, $16^{\circ} 30.526$ 'S, $151^{\circ} 45.101^{\prime} \mathrm{W}$

Material examined. Neotype (here designated). $\delta^{\Uparrow}(3.4 \mathrm{~mm})$, Bora Bora, fringing reef near Vaitape, FebMarch 1988, dead coral, $1 \mathrm{~m}$ (SMF 43367).

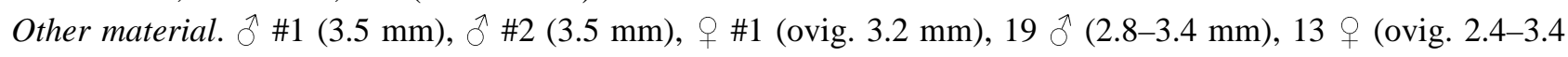
$\mathrm{mm}$ ), same data as neotype (SMF43368). Not measured: 36 今, 26 , 34 juveniles, same data as neotype (SMF 18624).

Additional material. $\widehat{\widehat{\gamma}}(3.3 \mathrm{~mm})$, Mooréa, fore-reef near Cook's Bay, $17.4761^{\circ} \mathrm{S}, 149.831^{\circ} \mathrm{W}, 7$ November

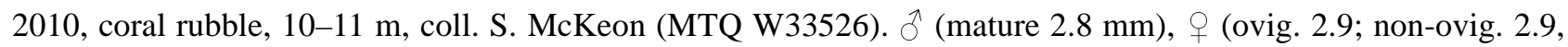
$2.6 \mathrm{~mm})$, juvenile $(1.6 \mathrm{~mm})$, Mooréa, Cooks Bay Hook, $17.4815^{\circ} \mathrm{S}, 149.8250^{\circ} \mathrm{W}, 11$ November 2010, coral rubble and Halimeda, coll. C. Watson (MTQ W33634).

Description of male. Body length 3.7 as long as greatest width; pereonite 1 medial width 2.4 length; pleotelson length 1.0 width.

Cephalon length 0.6 width; lateral margins acute, sparsely setose; antennal spines acute; eyes with 18-21 ommatidia, ommatidia orange, arranged in two parallel rows.

Antennula length 1.1 cephalon width; article 1 length 1.9 width, mesial margin with 1 short penicillate seta, anterolateral margin with 1 large penicillate seta; article 2 length 1.5 width, mesial margin with 1 cluster of setae, 1 penicillate seta, anterolateral margin with 2 clusters of setae, 1 penicillate seta; article 3 length 2.1 width, medial margin with 2 clusters of setae, anterolateral margin with 2 clusters of setae; article 4 length 0.5 width, anterior margin with 2 short setae, 1 penicillate seta; flagellum with 8 articles, flagellar article 1 distinctly longer than other flagellum articles, length 2.7 flagellar article 2 length. Antennae length 1.1 total body length, lateral margin with cluster of 3 setae; article 2 length 0.63 width, anterior margin with 2 short setae, lateral margin with cluster of 3 setae; article 3 length 1.5 width, mesiodistal margin with 2 clusters setae, 1 seta posterior to squama; article 4 length 0.5 width, distal margin with 2 short setae, mesiodistal margin with cluster of 2 setae; articles 5-6 length 3.1, 
7.4 width respectively; each flagellum article with a cluster of 4 anteriorly projecting setae, the cluster position serially repeating every 4 articles.

Mandible left spine row with 4 spines, right spine row with 11 spines; palp article 1 distolateral margin with 2 long setae; article 2 with submarginal row of 7 short serrate setae. Maxillula lateral lobe apex with 6 serrate setae; mesial lobe apex with 2 serrate setae. Maxilla mesial lobe mesial margin with 7 serrate setae. Maxilliped basis length 2.4 width, width 0.98 endite width; endite mesiodistal margin with 4 serrate setae, distal margin with 5 fan setae; palp article 2 length 0.9 basis width; epipod length 3.4 width, width 1.1 basis width, apex acute, mesial margin with 7 regularly spaced setae.

Pereopod 1 basis length 2.2 width, submarginal mesial ridge without setae. Ischium length 1.9 width; inferodistal margin with 3 short setae; superodistal margin not produced, setae absent; mediodistal margin with 8 long setae. Merus rectangular, length 1.6 width, length 3.0 as long as carpus; inferior margin densely covered with setae; inferodistal margin slightly produced; apex rounded; densely covered with long setae; superodistal margin not produced, with short setae. Carpus length 0.5 width; distal margin convex, short setae along margin length; carpal process length 2.3 width, extending to propodal palm articulation, curved, bladelike; inferior margin smooth, convex, sparsely setose, 1 row of stiff setae, 2 rows of long serrate setae; superior margin straight, setae regularly spaced. Propodus robust, length 1.4 width; inferior margin length 0.3 superior margin length, lightly setose, regularly spaced setae restricted to distal half of margin; superior margin sparsely setose, setae widely spaced, restricted to distal two-thirds of margin, superior mesial surface lightly covered with long, bi-denticulate setae; propodal palm oblique, margin with 1 medial tooth, short setae inserting between teeth, cluster of setae at articulation, terminal end with large, curved tooth. Dactylus 3.9 as long as basal width 1.3 propodal palm length, curved, distal margin sparsely setose, setae regularly spaced in clusters along entire length, opposing margin with regularly spaced short setae, mesial surface without setae. Pereopod 2 basis medial inferior margin with 1 stiff seta, superodistal margin with 3 penicillate setae; ischium superior margin apex with 1 stiff seta; merus superodistal apex with 1 stiff seta, inferodistal margin with 1 long seta, 1 short seta; carpus superodistal margin with 4 short and long setae, 1 penicillate seta, inferior margin with 4 flagellated RS setae, inferodistal margin with 1 RS, and 2 setae; propodus superior margin with regularly spaced setae, superodistal margin with 1 penicillate seta, 1 long seta, inferior margin with 4 flagellated RS. Pereopod 3 carpus inferior margin with 4 flagellated RS; propodus inferior margin with 3 flagellated RS. Pereopod 6 basis superior margin with 5 penicillate setae, inferior margin with 1 stiff seta; carpus inferior margin with 1 flagellated RS; propodus inferior margin with 3 flagellated RS. Pereopod 7 basis superior margin with 2 penicillate setae, inferior margin with 1 stiff seta; carpus inferior margin with 1 flagellated RS, propodus inferior margin with 3 flagellated RS.

Pleopod 1 protopod length 0.7 width, lateral margins with 1 seta, posterior lobes without pair of RS, surface setae present; rami lateral margins with regular setae along distal half of margin, apex with clustered setae, ventral surface with setae. Pleopod 2 protopod length 3.3 width; lateral margin with 1-2 setae; endopod proximal segment length 0.4 protopod length, without setae; appendix masculina length 1.4 endopod proximal length, 0.7 protopod length, lateral margin with distal groove, apex mediodistal margin hardened, without interior pocket of setae, 1 anteriorly projecting distolateral spine, 1 cluster of short setae distal to spine, mesial margin with evenly spaced setae. Pleopod 3 endopod apex with 5 plumose setae. Pleopod 4 exopod apex with 9 plumose setae. Pleopod 5 apex with 5 plumose setae.

Uropods length 0.6 pleotelson length; protopod length 1.8 width; endopod length 1.7 protopod length, 2 latitudinal rows of sensillate setae, distal and sub-distal margins with 8 penicillate setae; exopod length 1.0 protopod length, 2 latitudinal rows of sensillate setae.

Female. Pereopod 1 basis length 2.4 times as long as wide, mesial submarginal ridge with regular short setae; ischium superodistal process developed, acute; merus superodistal process developed, acute; carpus inferodistal process rounded; propodus 2.5 times as long as wide, with one row of setae and one row of serrate setae; propodal palm length 1.5 times propodus proximal width, 4 teeth along margin, row of serrate setae present; dactylus length 3.5 width, length 1.0 propodal palm length, proximal margin with 10 denticulate setae.

Pleopod 2 length 1.5 width; lateral margins with 2-5 setae, anterior half of margins straight and tapering; apex notched, asymmetric, 1 seta on each lobe; ventral surface without setae.

Size. Adult males 2.9-3.5 mm (mean $3.1 \mathrm{~mm}, \mathrm{n}=22$ ); ovigerous females 2.4-3.3 mm (mean $2.9 \mathrm{~mm}, \mathrm{n}=18$ ). Largest specimen, male $3.5 \mathrm{~mm}$ (male topotype \#1). 


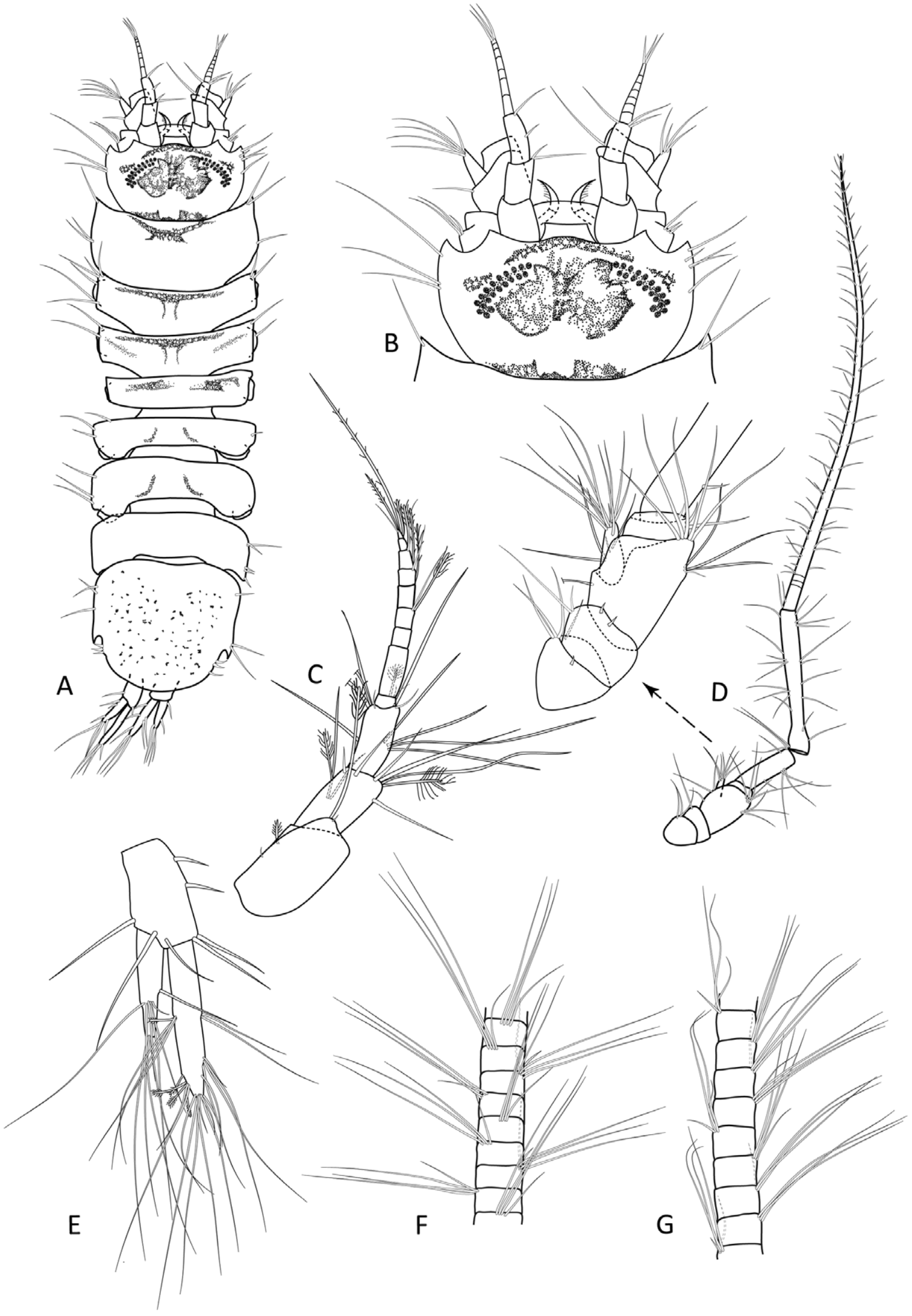

FIGURE 3. Hansenium hanseni Nobili, 1906. A, B, male neotype (SMF 43367). A, dorsal view; B, dorsal view of cephalon; C-F, male (SMF 18625); C, antennula; D, antenna with enlargement of articles and squama; E, uropod; F, enlargement of antenna flagellum articles; G, female (SMF 43368), enlargement of antenna flagellum articles. 


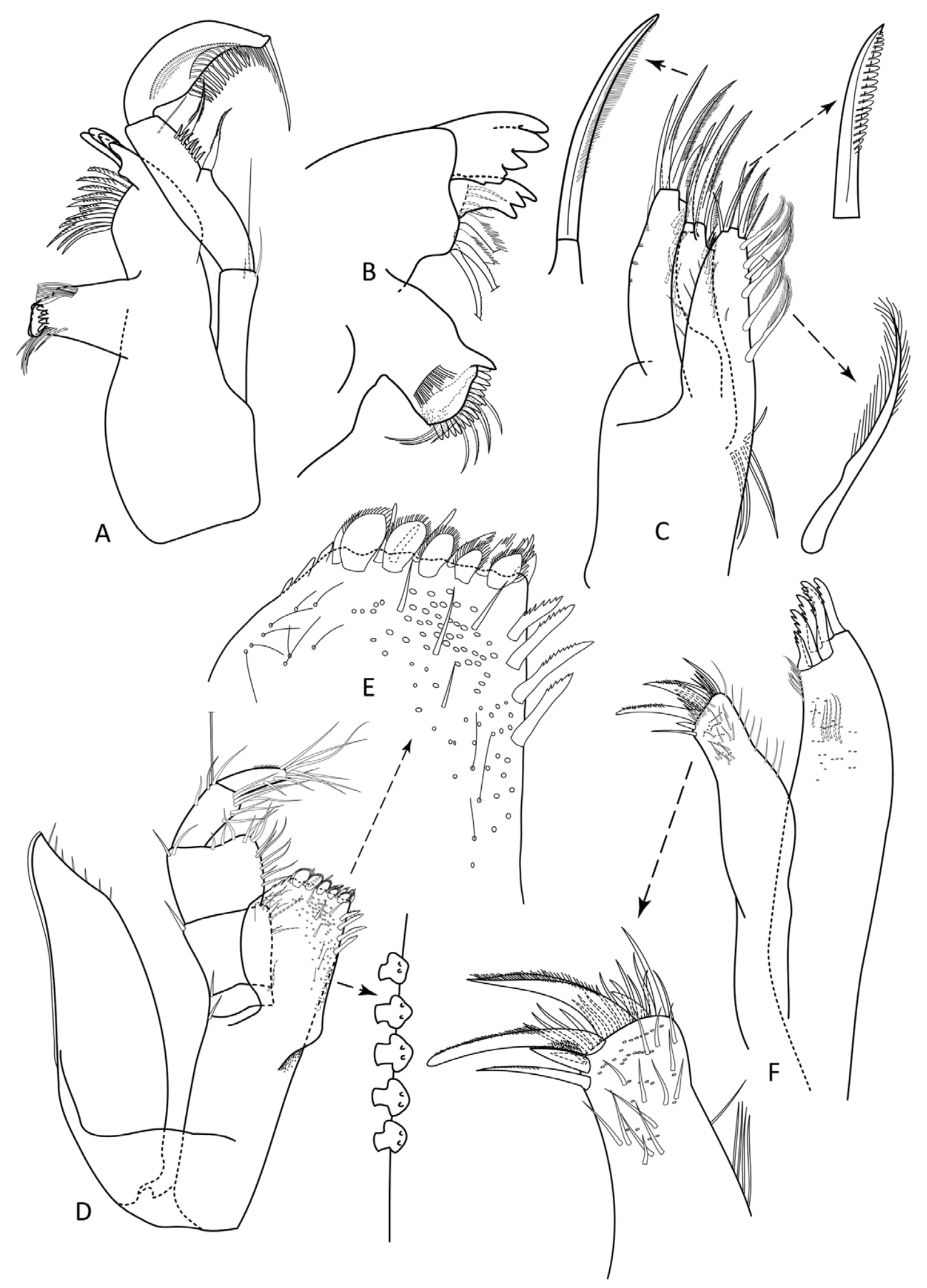

FIGURE 4. Hansenium hanseni Nobili. Male (SMF 43368). A, right mandible with palp; B, left mandible; C, left maxilla with enlargements of setal types; D, left maxilliped with enlargement of coupling hooks; E, detail of left maxilliped endite; F, left maxillula with detail of mesial lobe. 


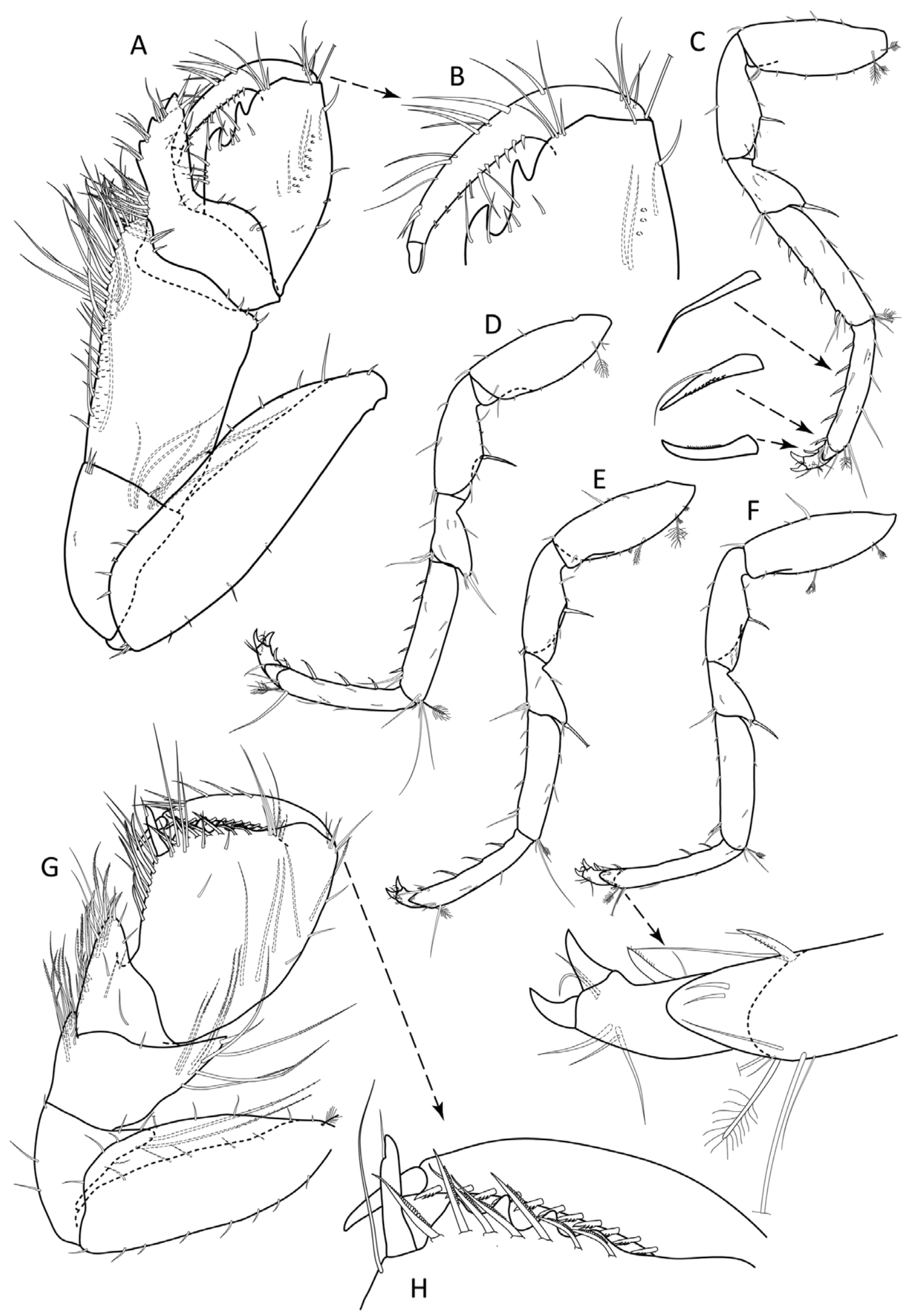

FIGURE 5. Hansenium hanseni Nobili. A, B, male neotype (SMF 43367): A, pereopod 1; B, detail of dactylus; C-F, male \#1: C, pereopod 2; D, pereopod 3; E, pereopod 6; F, pereopod 7, with enlargement of dactylus; G, H, female : G, pereopod 1; H, enlargement of dactylus of pereopod 1 (SMF 43368). 

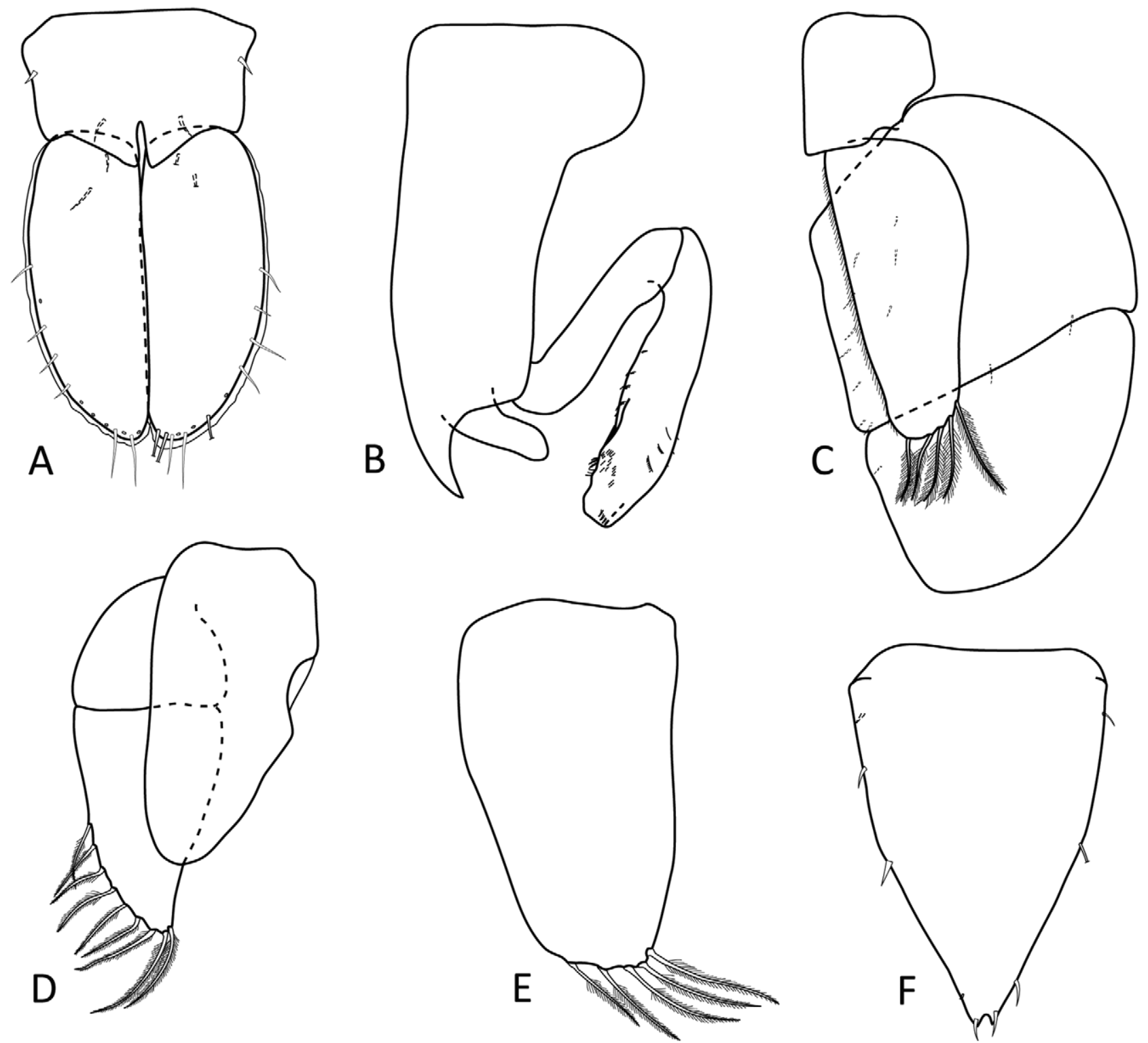

FIGURE 6. Hansenium hanseni Nobili. A-E, male \#1, A, pleopod 1; B, pleopod 2; C, pleopod 3; D, pleopod 4; E, pleopod 5; F, female, pleopod 2 (SMF 18624).

Variation. Müller (1991a) describes the pereopod 1 carpal process as having five teeth (serrations) on the inferodistal margin. Although most mature males possess five serrations, the serration count varies between 4-5 serrations in specimens examined.

Colour. The cephalon has a 'butterfly-shaped' pattern mesial to the eyes and a band along anterior margin of cephalon extending just medial of antennal teeth apex. Pereonites $1-4$ with medial markings along anterior margins only. Pereonite 7 without pigmentation, pleotelson speckled across entire dorsal surface.

Remarks. Hansenium hanseni may be identified by the male pereopod 1 having a strongly produced, terminally acute, serrated carpal process and an elongate and quadrate merus. $H$. remocarpus differs from $H$. hanseni by the pereopod 1 carpal process being weakly serrated and a far shorter merus (1.6 longer than wide in $H$. remocarpus vs 2.0 in $H$. hanseni).

Distribution. Bora Bora and Mooréa, Society Islands; 'Laguna di Fakahina, Polinesia' (Nobili 1906, 1907), Fakahina Atoll, Tuamotus (approximately 700 km East of Bora Bora). 


\section{Machatrium gen. nov.}

Type species: Machatrium falcensis sp. nov., here designated.

Species included. Machatrium falcensis sp. nov., type species, Great Barrier Reef; Machatrium spathulicarpus (Kensley, 1984), comb. nov., Belize; Machatrium tropex (Bolstad \& Kensley, 1999), comb. nov., Papua New Guinea; Machatrium thunku sp. nov., Great Barrier Reef. All of these species have an long carpal blade (1.5-4.2 as long as wide), extending to half way along inferior margin of the propodus and up to the distal margin of the propodus.

The following species have a moderately long carpal blade (1.3-1.5 as long as wide) that extends up to half way along the propodus inferior margin: Machatrium aldabrae (Kensley \& Schotte, 2002), comb. nov., Aldabra Island, Western Indian Ocean; Machatrium monodi (Nordenstam, 1946), comb. nov., Gulf of Suez, Egypt (Monod 1933); Machatrium monodi, of Kensley and Schotte, 2002, comb. nov., Mahé, Seychelles (not S. monodi Nordenstam); Machatrium wongat sp. nov., Papua New Guinea; Machatrium zanzibarica (Kensley \& Schotte, 2002), comb. nov., Zanzibar, Tanazania, East Africa [this species keys to Hansenium in Kensley and Schotte (2002), and appears near identical to Hansenium aldabrae].

Diagnosis (male). Cephalon lateral teeth acute, antennal teeth sub-equal in length to lateral, acute or rounded. Pseudorostrum truncate, trapezoid, wider than long. Eyes large (more than 12 ommatidia), reniform. Male pereopod 1 carpus inferodistal process smooth, spatulate; propodus elongate (length at least 2.5 times longer than wide), propodal palm transverse with 3-5 teeth, a terminal seta present. Male pleopod 2 appendix masculina distally broad, terminally concave with fringe of setae and interior pocket of setae, distolateral margin with 2-5 proximally directed spines.

Description (male). Body dorsal surface smooth or sparsely setose, widest at pereonite 1 ; pereonite 1 length greater than 1.5 times pereonite 2 length; pereonites 2-4 lateral margins convex, anteriorly acute. Pleotelson subequal to width; lateral margins smooth, sub-parallel, posterolateral spines prominent, margin posterior to spines rounded with weak apical point; dorsal surface smooth, or sparsely setose.

Cephalon lateral margins smooth. Antennae length equal or longer than total body length, article 1 lateral spine absent.

Pereopod 1 basis superior margin with regularly spaced setae along length, superior submarginal ridge with row of setae; merus angular; carpus inferodistal margin with well-developed process; propodal palm with teeth along palm margin,; dactylus length subequal to propodal palm length.

Pleopod 1 protopod rectangular, lateral margin setae present; rami lateral margins evenly convex. Pleopod 2 protopod longer than wide, distal apex sharply pointed; appendix masculina lateral margin groove absent. Pleopod 5 distal apex with 3-5 plumose setae.

Female. Generally similar to male but for primary sexual characters. The pereopod 1 in females is much smaller, less ornamented and less setose.

Remarks. Machatrium gen. nov. is characterised by the male pereopod 1 having an elongate propodus, spatulate and smooth carpal process and pleopod 2 appendix masculina apex being concave and fringed with setae. The principle differentiating and diagnostic characters that separate Machatrium from both Hansenium and Stenetrium are presented in Table 2.

Distribution. The genus is known only from tropical coral reefs, with a worldwide distribution.

Etymology. Derived from the Latin 'machaerium' meaning bent sword and '-trium' indicating family affinity; gender neuter.

\section{Machatrium falcensis sp. nov.}

(Figures 7-10)

Material examined: Holotype. $\widehat{\delta}(5.0 \mathrm{~mm})$, east of South Direction Island, southwestern reef slope at High Rock, $14.82428^{\circ} \mathrm{S}, 145.5527^{\circ} \mathrm{E}, 11$ September 2010 , coralline algae-covered coral rubble, $30 \mathrm{~m}$, coll. S. Smith (MTQ W33805).

Paratypes. Oे $(3.5 \mathrm{~mm}), 7$ q $(4$ ovig. 3.8-4.6; non-ovig. 5.0, 3.5, $3.5 \mathrm{~mm}), 3$ mancas (1.8-1.9 mm), same data as holotype (MTQ W33808). ${ }^{\lambda}$ (4.7 mm [dissected]), + (ovig. $4.6 \mathrm{~m}$ ), Lizard Island, lagoon entrance from Bird 
Islet, $14.689^{\circ} \mathrm{S}, 145.4671^{\circ} \mathrm{E}, 19$ April 2008 , dead robust Acropora branches, $15 \mathrm{~m}$, coll. M. Błażewicz-Paszkowycz

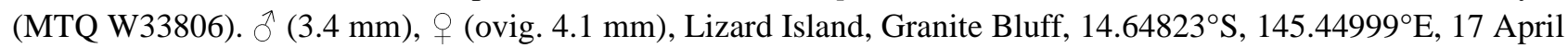
2008, large coral rubble, 15 m, coll. M. Błażewicz-Paszkowycz (MTQ W33807). 2 ^ (4.1, 3.3 mm), (ovig. 3.3; non-ovig. $4.0 \mathrm{~mm})$, juvenile $(2.4 \mathrm{~mm})$, Lizard Island, Granite Bluff, $14.64823^{\circ} \mathrm{S}, 145.44999^{\circ} \mathrm{E}, 17$ April 2008, coral rubble in depression on coral reef, $15 \mathrm{~m}$, coll. M. Błażewicz-Paszkowycz (MTQ W14061). $6 \widehat{\jmath}(3.3-5.5 \mathrm{~mm}$ ), 2 ㅇ (ovig. 4.0; non-ovig. $3.0 \mathrm{~mm}$ ), 2 juv. (3.4, $2.0 \mathrm{~mm}$ ), McGillivray Reef, $14.6583^{\circ} \mathrm{S}, 145.4917^{\circ} \mathrm{E}, 29$ August 2010, coral rubble, $15 \mathrm{~m}$, coll. CB (MTQ W32591). 2 क (4.0, $4.3 \mathrm{~mm}$ North Direction Island, $14.7511^{\circ} \mathrm{S}$, $145.5126^{\circ} \mathrm{E}, 3$ September 2010, coral rubble, $28 \mathrm{~m}$, coll CB (MTQ W32771, W32772).

TABLE 2. Principle differentiating characters for Hansenium, Stenetrium and Machatrium gen. nov. Putative apomorphic characters (bold) are identified on the basis of comparison to the Pseudojaniridae (and Gnathostenetroidae). Principal published sources are Serov and Wilson (1995) for Stenetrium and Serov and Wilson (1999) for Pseudojaniridae. Fresh material for these taxa was also examined.

\begin{tabular}{|c|c|c|c|c|}
\hline Character & Pseudojaniridae & Hansenium & Machatrium gen. nov. & Stenetrium \\
\hline 1. Antenna 2 , article 1 & without lateral spine & $\begin{array}{l}\text { without lateral } \\
\text { spine }\end{array}$ & without lateral spine & with lateral spine \\
\hline 2. Pseudorostrum & $\begin{array}{l}\text { rostrum triangular or } \\
\text { rounded }\end{array}$ & $\begin{array}{l}\text { pseudorostrum } \\
\text { trapezoid, wider } \\
\text { than long }\end{array}$ & $\begin{array}{l}\text { pseudorostrum } \\
\text { trapezoid, wider than } \\
\text { long }\end{array}$ & $\begin{array}{l}\text { triangular or rounded; } \\
\text { may be a 'true rostrum' }\end{array}$ \\
\hline 3. Pereopod 1 propodus & $\begin{array}{l}\text { inferior margin blade } \\
\text { like }\end{array}$ & $\begin{array}{l}\text { inferior margin } \\
\text { thick, not blade- } \\
\text { like }\end{array}$ & $\begin{array}{l}\text { inferior margin blade- } \\
\text { like }\end{array}$ & $\begin{array}{l}\text { inferior margin blade- } \\
\text { like }\end{array}$ \\
\hline 4. Pereopod 1 propodus & short (1.0-1.4 L/W) & $\begin{array}{l}\text { moderate (1.6-2.0 } \\
\mathrm{L} / \mathrm{W})\end{array}$ & elongate $(1.5-2.4 \mathrm{~L} / \mathrm{W})$ & $\begin{array}{l}\text { Short }(1.0-1.3) \text { (from } \\
\text { Serov and Wilson } \\
1995)\end{array}$ \\
\hline $\begin{array}{l}\text { 5. Pereopod } 1 \text { propodus } \\
\text { palm }\end{array}$ & transversely truncate & $\begin{array}{l}\text { Oblique with } \\
\text { mid-margin } \\
\text { inflection }\end{array}$ & $\begin{array}{l}\text { transversely truncate or } \\
\text { distally inflected }\end{array}$ & transversely truncate \\
\hline $\begin{array}{l}\text { 6. Pereopod } 1 \text { carpus } \\
\text { inferior margin }\end{array}$ & without carpal blade & $\begin{array}{l}\text { long serrated } \\
\text { blade }\end{array}$ & long spatulate blade & without carpal blade \\
\hline 7. Pereopod 1 merus & short & quadrate & angular & $\begin{array}{l}\text { angular (from Serov } \\
\text { and Wilson 1995) }\end{array}$ \\
\hline 8. Appendix masculina & without apical setae & $\begin{array}{l}\text { without apical } \\
\text { setae }\end{array}$ & with apical setae & with apical setae \\
\hline
\end{tabular}

Description of male. Body length 4.3 greatest width; pereonite 1 medial width 2.9 length; pleotelson length 1 width.

Cephalon length 0.6 width; lateral margins acute, sparsely setose; antennal spines acute; eyes with 14-16 ommatidia, ommatidia pale brown, arranged in two parallel rows.

Antennula length 1.1 cephalon width; article 1 length 1.9 width, mesial margin with 6 short penicillate setae, anterolateral margin with 1 large penicillate seta; article 2 length 2.1 width, mesial margin with 1 cluster of setae, 1 penicillate seta, anterolateral margin with 1 cluster of setae, 1 penicillate seta; article 3 length 2.4 width, medial margin with 1 cluster of setae, anterolateral margin with 1 cluster of setae; article 4 length 0.4 width, anterior margin with 2 short setae, 1 penicillate seta; flagellum with 15 articles, flagellar article 1 distinctly longer than other articles, length 2.1 flagellar article 2 length. Antennae length 1.0 total body length; articles 5-6 length 7.2, 9.5 width respectively; each flagellum article with a cluster of 3-4 anteriorly projecting setae, the cluster position serially repeating every 4 articles.

Mandible left spine row with 4 spines, right spine row with 8 spines; palp article 1 distolateral margin with 1 long seta; article 2 with submarginal row of 7 short serrate setae. Maxillula lateral lobe apex with 10 serrate setae; mesial lobe apex with 2 serrate setae. Maxilla mesial lobe mesial margin with 8 serrate setae. Maxilliped basis length 2.3 width, width 0.92 endite width; endite mesiodistal margin with 6 serrate setae, distal margin with 5 fan 
setae; palp article 2 length 0.8 basis width; epipod length 3.1 width, width 1.2 basis width, apex acute, mesial margin with 6 regularly spaced setae.

Pereopod 1 basis length 3.9 width, submarginal mesial ridge with regularly spaced setae along length. Ischium length 1.8 width; inferodistal margin with 1 short seta; superodistal margin strongly produced, acute, densely covered with long setae; mediodistal margin with 6 long setae. Merus angular, length 1.0 width, length 1.2 carpus length; inferior margin lightly covered with setae; inferodistal margin not produced; superodistal margin strongly produced, apex acute, densely covered with long setae. Carpus length 0.8 width; distal margin convex, short setae along margin length; carpal process long, length 4.2 width, extending about halfway along propodal palm, curved, spatulate; inferior margin smooth, convex, densely setose, 1 row of stiff setae, 2 rows of long serrate setae; superior margin slightly concave, setae regularly spaced. Propodus inferior half of article flattened, length 3.7 width; inferior margin length 0.7 superior margin length, lightly setose, regularly spaced setae along entire length; superior margin setose, setae regularly spaced, restricted to distal two-thirds of margin, superior mesial surface densely covered with long, bi-denticulate setae; propodal palm with 3 medial teeth, row of long setae, row of short setae on each side of margin, cluster of setae at articulation, terminal end with single RS. Dactylus width 4.7 times as long as basal width, length 1.05 propodal palm length, curved, distal margin setose, setae widely spaced along entire length, opposing margin with regularly spaced rows of setae and serrate setae, mesial surface densely setose. Pereopod 2 basis medial inferior margin with stiff seta absent, anterosuperior margin with 3 penicillate setae; ischium superior margin apex with 1 stiff seta; merus superodistal apex with 1 stiff seta, inferodistal margin with 1 long seta, 2 short setae; carpus superodistal margin with 4 short and long setae, 1 penicillate seta, inferior margin with 5 flagellated RS, inferodistal margin with 1 RS, and 3 setae; propodus superior margin with regularly spaced setae, superodistal margin with 1 penicillate seta, 1 long seta, inferior margin with 5 flagellated RS. Pereopod 7 basis superior margin with 1 penicillate seta, inferior margin with 1 stiff seta; carpus inferior margin with 2 flagellated RS, propodus inferior margin with 5 flagellated RS.

Pleopod 1 protopod length 0.7 width, lateral margins with more than 1 seta, posterior lobes with pair of RS, surface setae absent; rami lateral margins with regular setae along distal two-thirds of margin, apex with clustered setae, ventral surface with setae. Pleopod 2 protopod length 2.8 width; lateral margin with greater than 2 setae; endopod proximal segment length 0.5 protopod length, without setae; appendix masculina length 1.5 endopod proximal length, 0.8 protopod length, lateral margin without distal groove, apex concave, depression fringed with setae, interior pocket present with fine setae, 2 anteriorly projecting distolateral spines, mesial margin without setae. Pleopod 3 endopod apex with 5 plumose setae. Pleopod 4 exopod apex with 9 plumose setae. Pleopod 5 apex with 4 plumose setae.

Uropods length 0.6 pleotelson length; protopod length 2.9 width; endopod length 1.0 protopod length, 2 latitudinal rows of sensillate setae, distal and sub-distal margins with 7 penicillate setae; exopod length 0.7 protopod length, 2 latitudinal rows of sensillate setae.

Female. Pereopod 1 basis length 3.3 times as long as wide, mesial submarginal ridge with regular short setae; ischium superodistal process developed, acute; merus superodistal process developed, acute; carpus inferodistal process rounded; propodus 3.7 times as long as wide, with one row of setae and one row of serrate setae; propodal palm length 1.8 times propodus proximal width, 4 teeth along margin, row of serrate setae present; dactylus length 3.8 width, length 1.0 propodal palm length, proximal margin with 11 denticulate setae.

Pleopod 2 length 1.4 width; lateral margins with 6 or more setae, anterior half of margins slightly concave; apex pointed, without setae; ventral surface without setae.

Size. Largest specimens: male $5.0 \mathrm{~mm}$ (holotype), female $5.0 \mathrm{~mm}$ (topotype). Adult males $3.3-5.0 \mathrm{~mm}$ (mean 4.07, $\mathrm{n}=8$ ); ovigerous females 3.3-4.6 $\mathrm{mm}$ (mean $3.9 \mathrm{~mm}, \mathrm{n}=8$ ).

Coloration. Eyes pale brown, cephalon with thin, solid line along anterior margin, two distinct pigmentation spots mesial to the eyes extending from anterior margin to eye mesial curvature, pigmentation on pereonites 1-4 on both anterior and posterior margins, pleotelson with a light 'reticulated pattern (as opposed to simple spotting) across entire dorsal surface, this pattern visible on juveniles and mancas.

Remarks. Machatrium falcensis sp. nov. can be identified by the inferior propodal margin of male pereopod 1 abruptly narrowing proximally, giving a 'hatchet-like' appearance to the propodus; the carpal process is narrow (4.2 as along as width) and curved; and the propodal palm has three teeth. M. falcensis has relatively long antennula with more than 10 flagellar articles. 


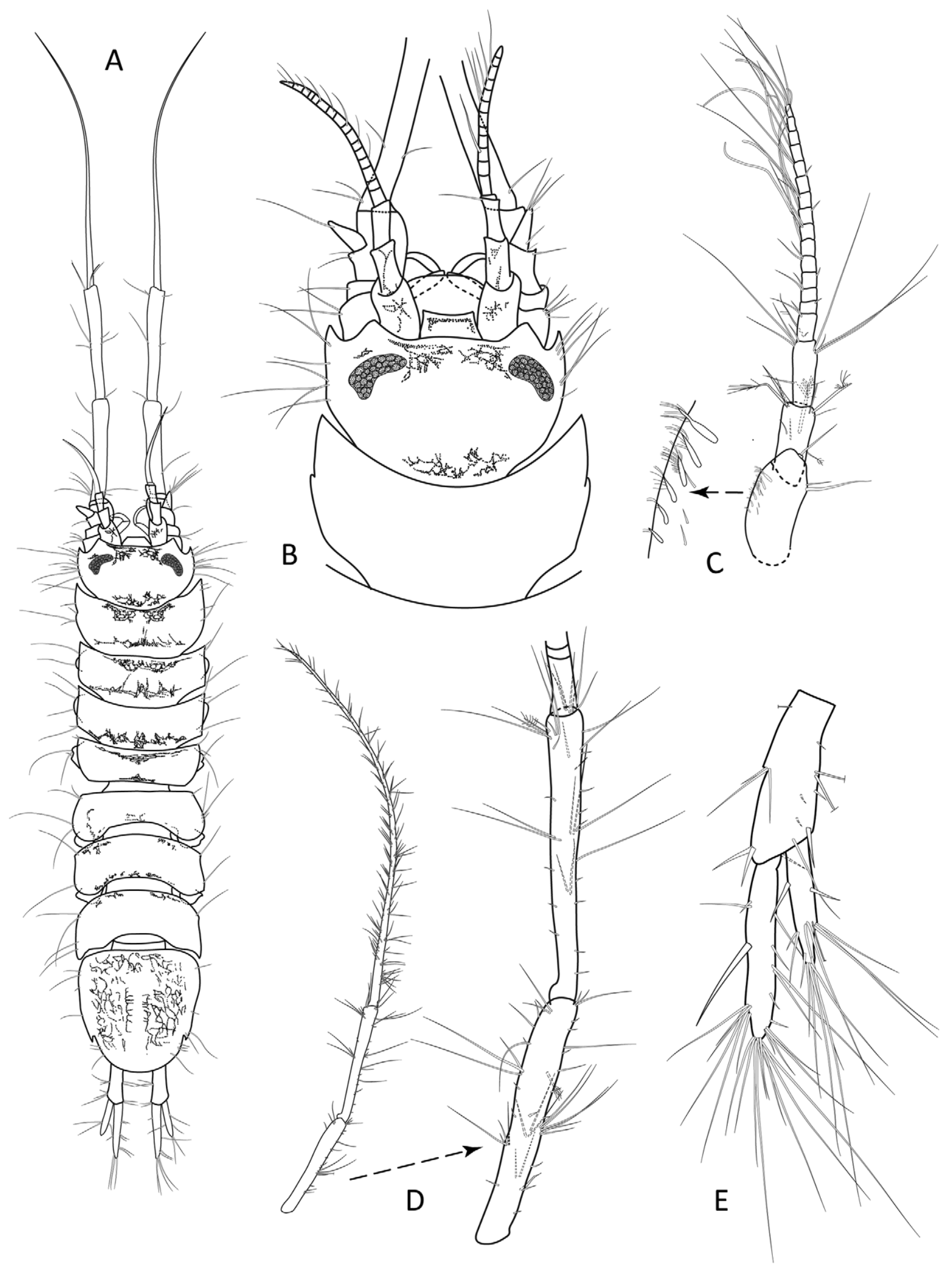

FIGURE 7. Machatrium falcensis sp. nov. Male holotype (MTQ W33805). A, dorsal view; B, dorsal view of cephalon; C, antennula with detail of marginal setae; D, antenna flagellum articles; E, uropod. 


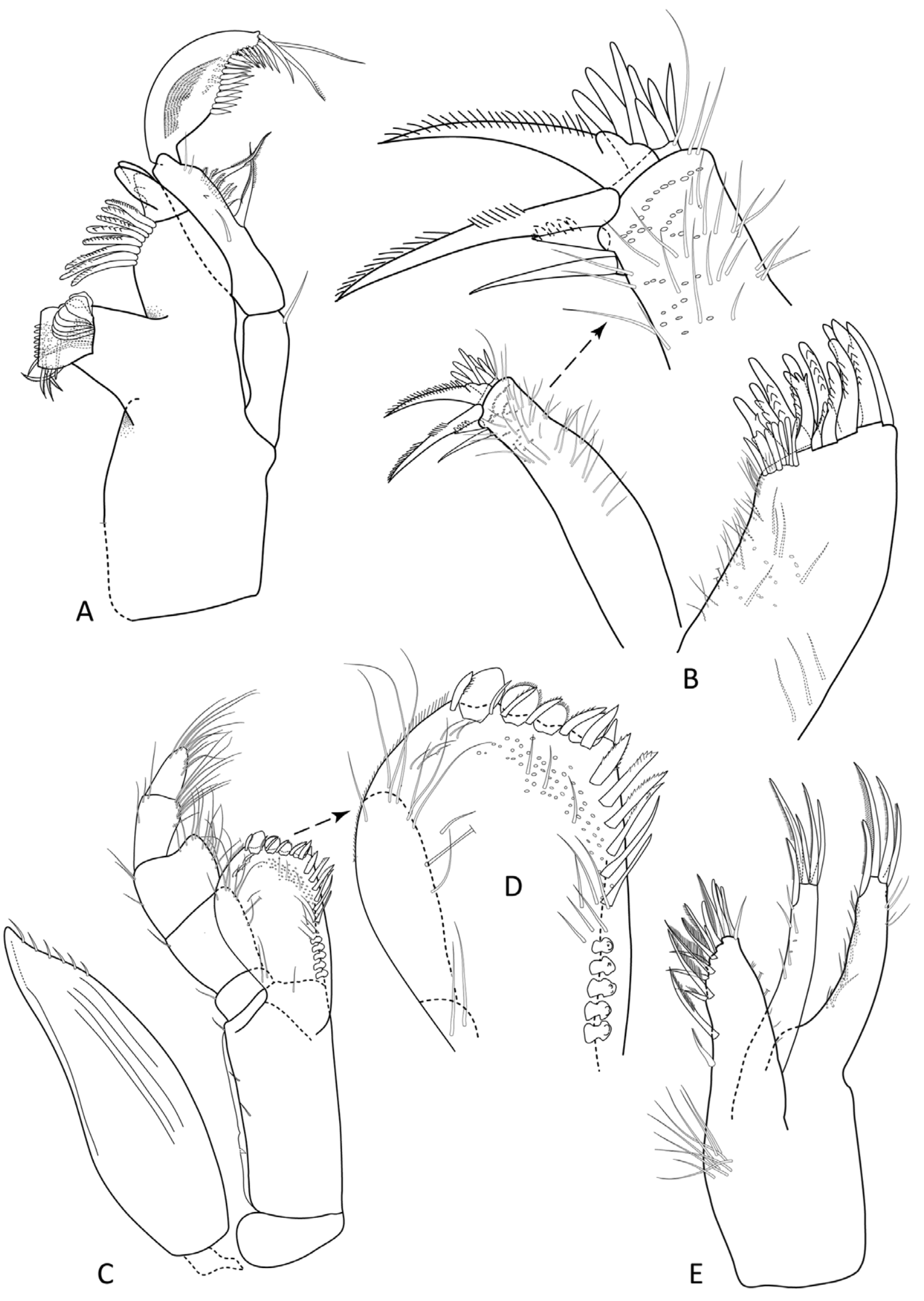

FIGURE 8. Machatrium falcensis sp. nov. Male paratype (MTQ W33806). A, right mandible; B, maxillula, with detail of mesial lobe; C, maxilliped; D, maxilliped endite; E, maxilla. 


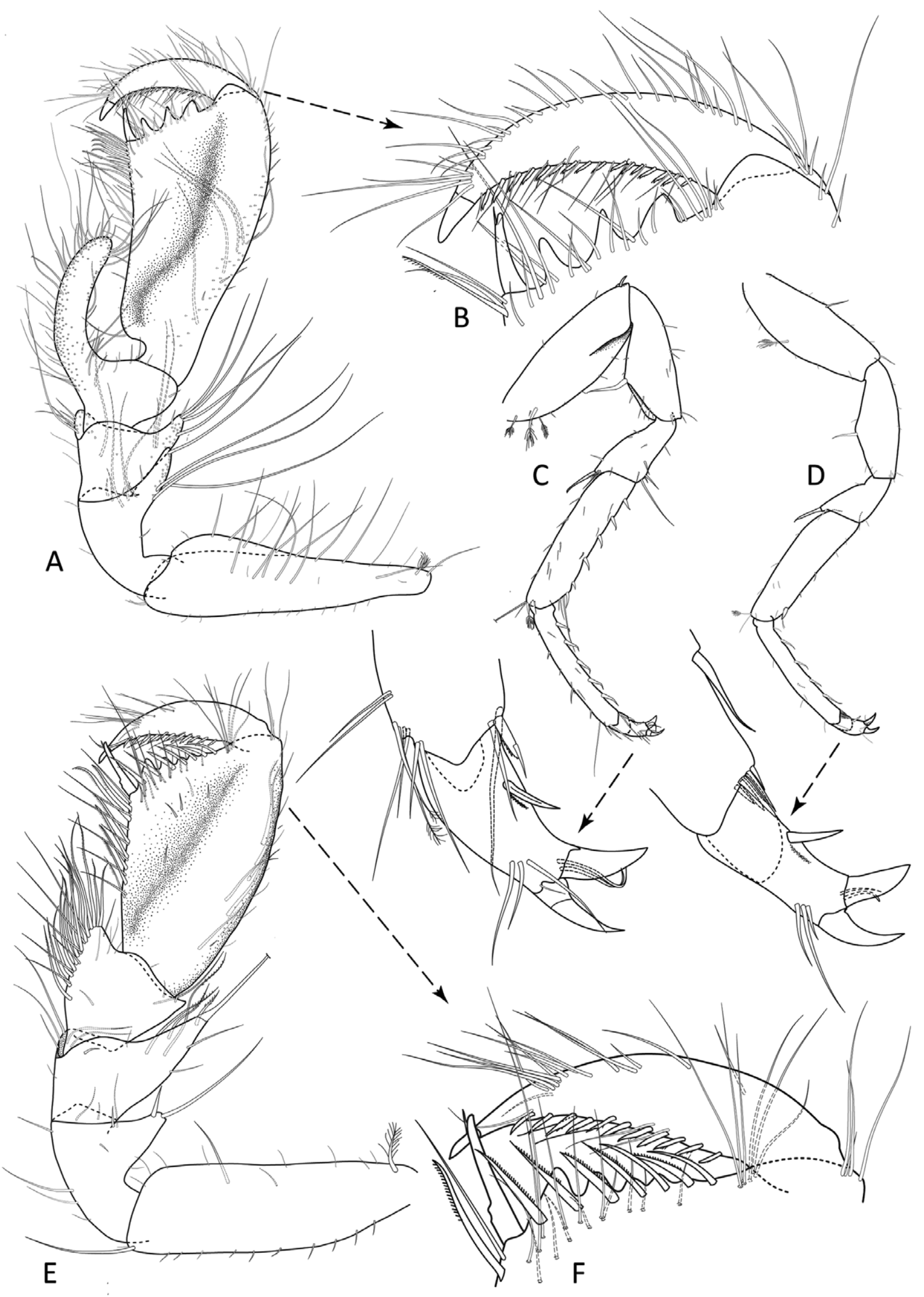

FIGURE 9. Machatrium falcensis sp. nov. A, B, male holotype (MTQ W33805), pereopod 1; B, enlargement of pereopod 1 dactylus; C, D, male paratype (MTQ W33806): C, pereopod 2; D, pereopod 7; E, F, female paratype (MTQ W33806): E, pereopod $1 ; \mathrm{F}$, enlargement of pereopod 1 dactylus. 

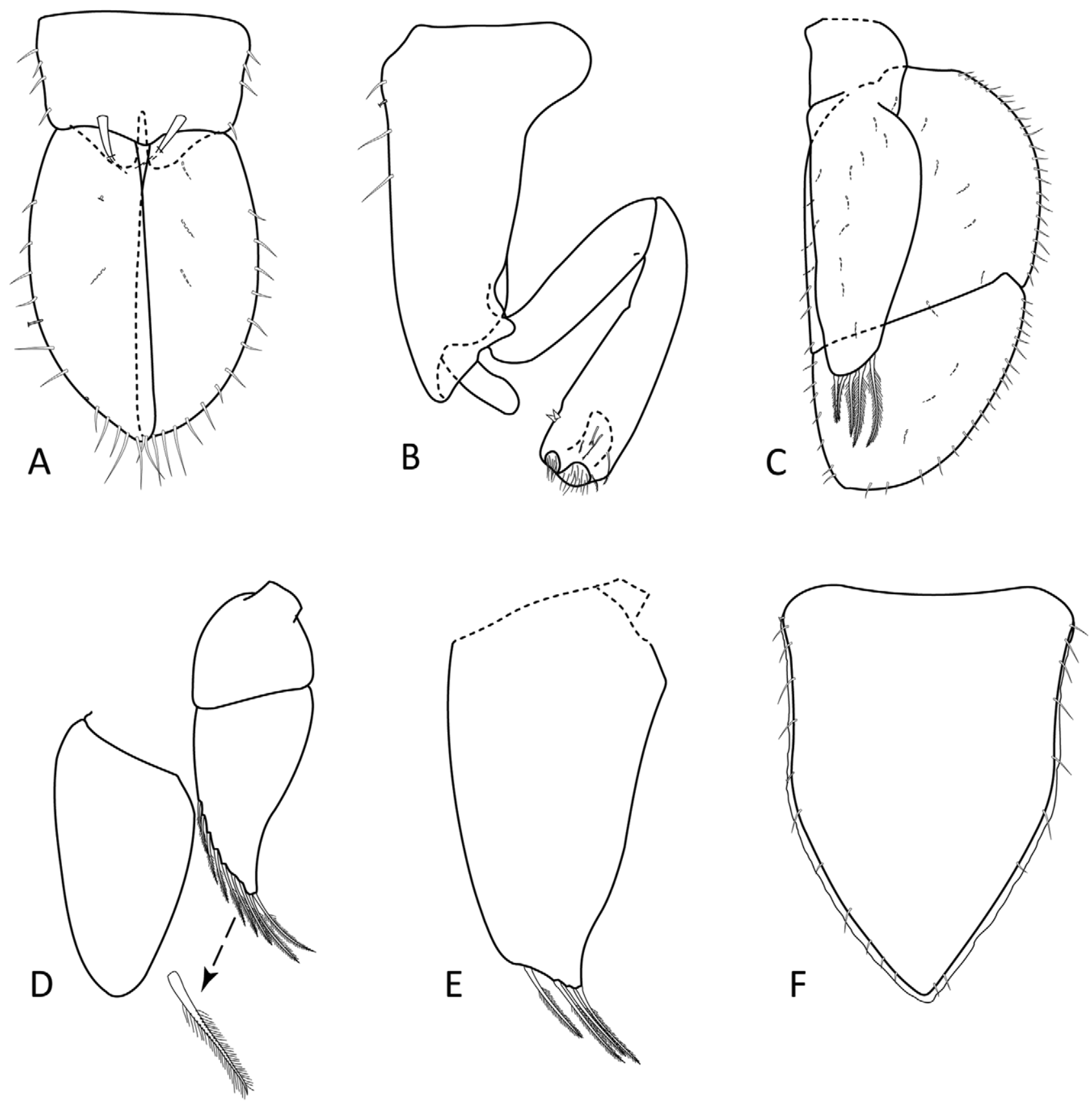

FIGURE 10. Machatrium falcensis sp. nov. A-E, male paratype (MTQ W33806), A, pleopod 1, dorsal view; B, pleopod 2; C, pleopod 3; D, pleopod 4 with enlargement of plumose seta; E, pleopod 5; F, female paratype (MTQ W33806), pleopod 2.

Distribution. Lizard Island and Bird Islet, Lizard Island Group and High Rock, east of South Direction Island; at depths of 15 to 30 metres.

Etymology. Derived from the Latin 'falc' meaning sickle and 'ensis' meaning sword, alluding to the carpal process on pereopod 1 .

\section{Machatrium thungku sp. nov.}

(Figures 11-14)

Material examined: Holotype. $\widehat{O}^{\Uparrow}(4.3 \mathrm{~mm})$, Lizard Island region, Day Reef, $14.47119^{\circ} \mathrm{S}, 145.5297^{\circ} \mathrm{E}, 13$ February 2009, outer reef front slope, coral rubble, 10 m, coll. M. Błażewicz-Paszkowycz (MTQ W31367).

Paratypes. $\widehat{O}(4.0 \mathrm{~mm}), 2$ (non-ovig. 4.2 juv. $2.7 \mathrm{~mm}$ ), same data as holotype (MTQ W34000). 


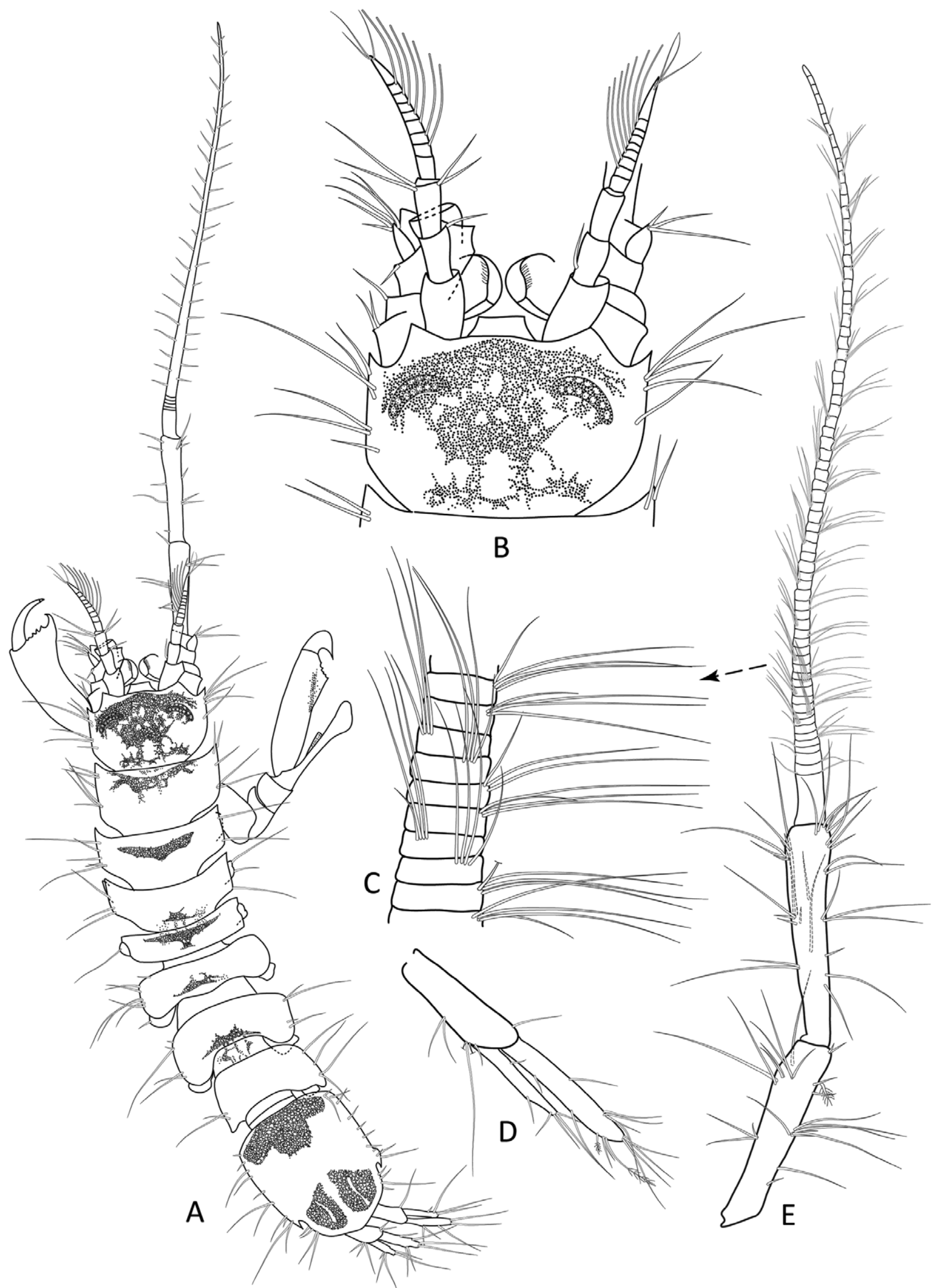

FIGURE 11. Machatrium thungku sp. nov. Male holotype (MTQ W31367). A, dorsal view; B, dorsal view of cephalon; C, enlargement of antenna flagellum articles; D, uropod; E, antenna. 


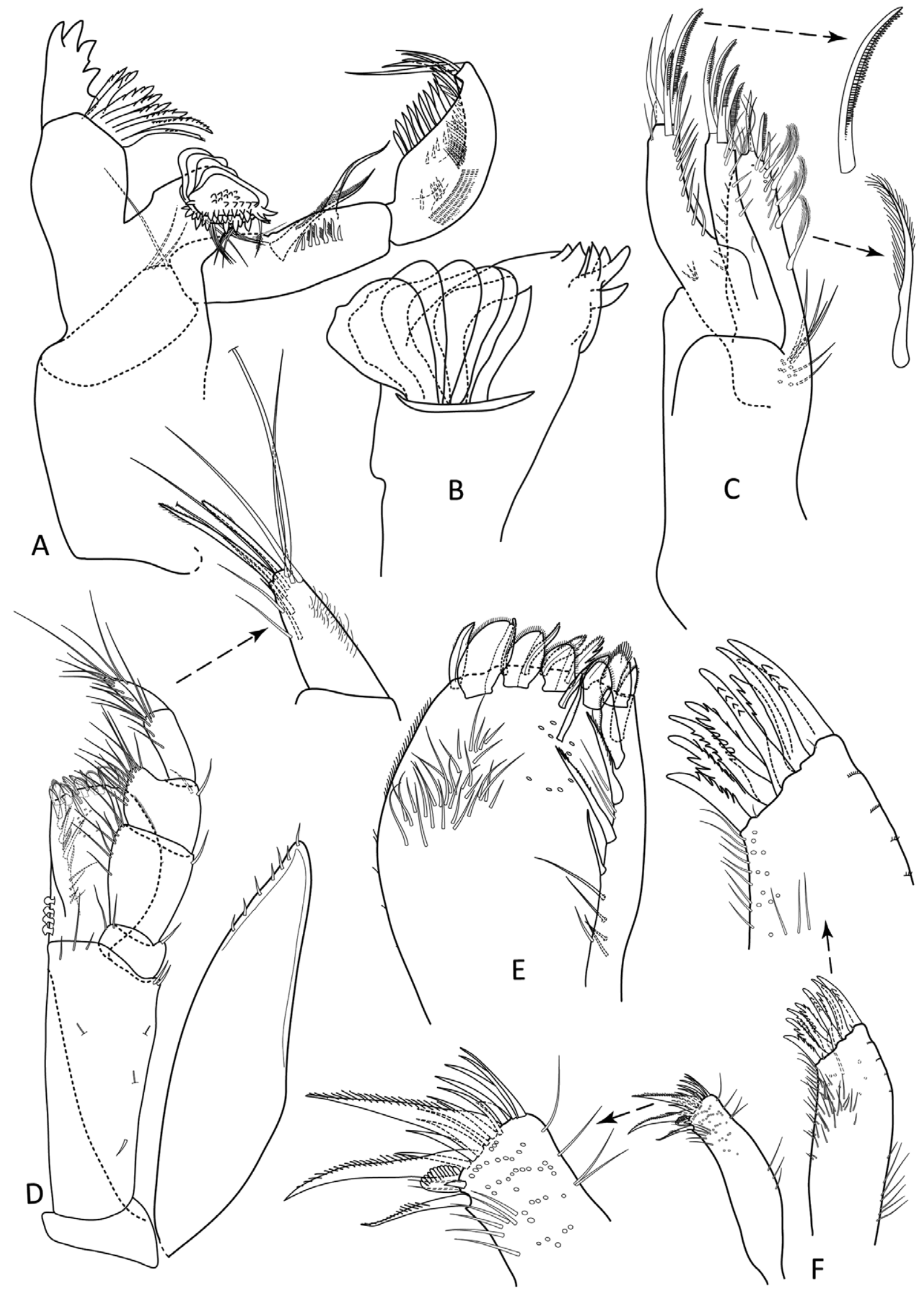

FIGURE 12. Machatrium thungku sp. nov. Male paratype (MTQ W34000). A, right mandible; B, detail of mandibular molar process; C, right maxilla with enlargement of setae; D, left maxilliped, with enlargement of palp article 5; E, maxilliped endite; $\mathrm{F}$, left maxillula, with detail of lobe apices. 


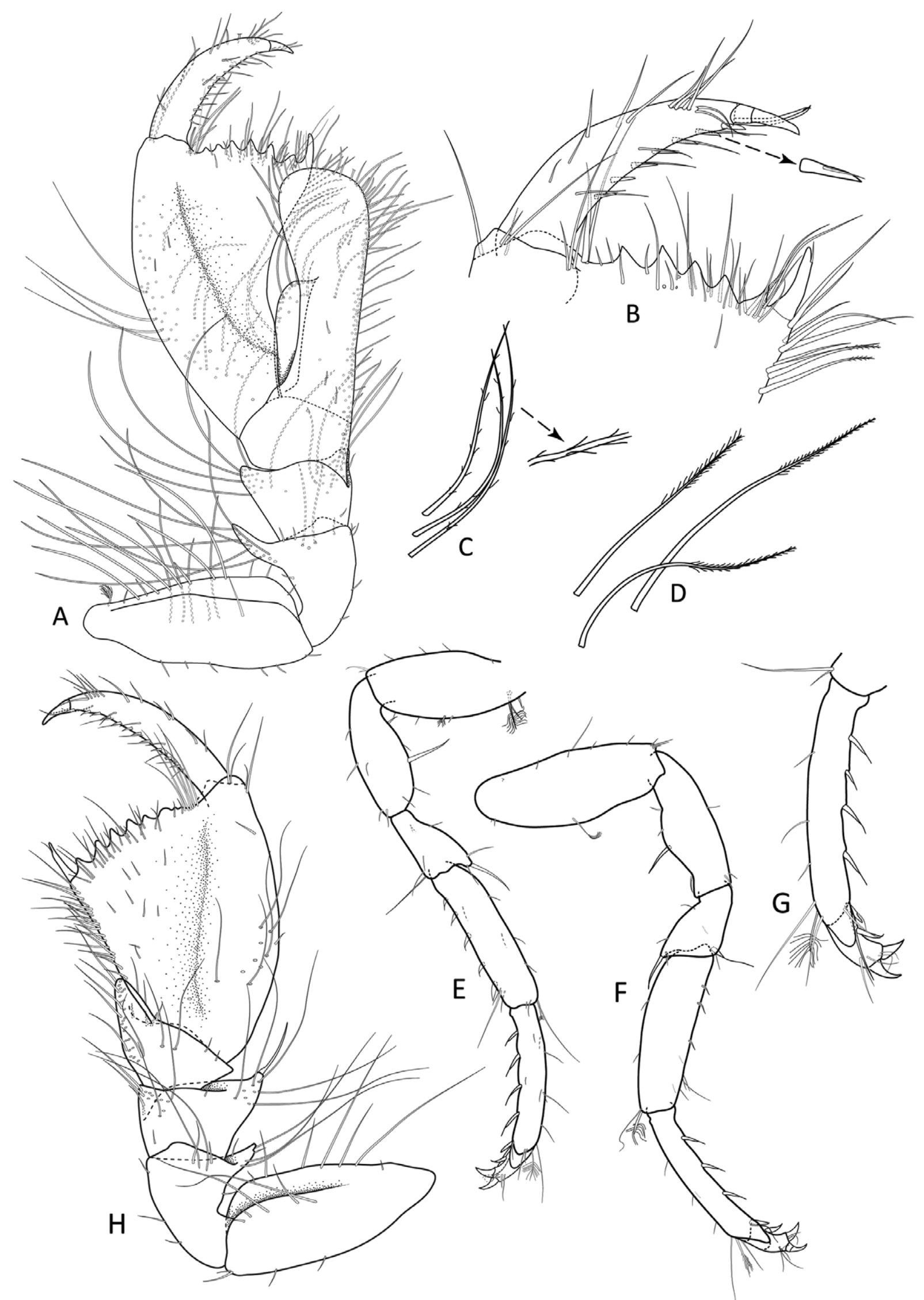

FIGURE 13. Machatrium thungku sp. nov. A, male holotype (MTQ W31367) pereopod 1; B-F, male paratype (MTQ W34000); B, pereopod 1, enlargement of dactylus; C, pereopod 1, merus setae on dorsal margin; D, carpal process and propodal margin setae; E, pereopod 2; F, pereopod 7; G, H, female paratype (MTQ W34000): G, pereopod 7; H, pereopod 1. 

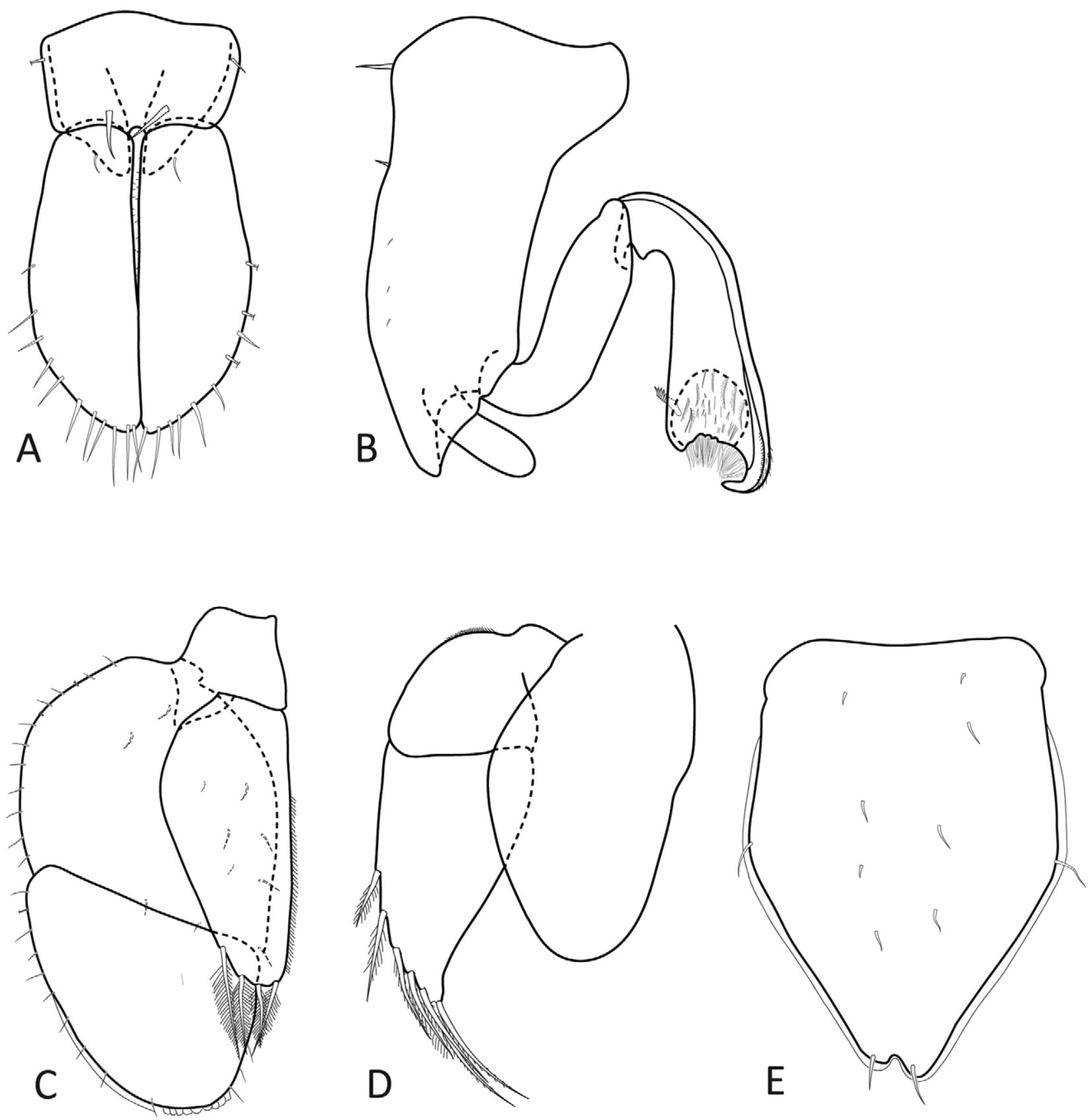

FIGURE 14. Machatrium thungku sp. nov. Male holotype (MTQ W31367). A, pleopod 1, dorsal view; B, pleopod 2; C, pleopod 3; D, pleopod 4; E, female paratype (MTQ W34000) pleopod 2.

Description of male. Body length 4.7 as greatest width; pereonite 1 medial width 1.9 length; pleotelson length 1.2 width.

Cephalon length 0.6 width; lateral margins acute, sparsely setose; antennal spines rounded; eyes with 12-18 ommatidia, ommatidia dark brown, arranged in two parallel rows.

Antenna length 1.1 total body length; articles 5-6 length 4.4, 5 width respectively; each flagellum article with a cluster of 4 anteriorly projecting setae, the cluster position serially repeating every 4 articles.

Mandible right spine row with 8 spines; article 2 with submarginal row of 7 short serrate setae. Maxillula lateral lobe apex with 9 serrate setae; mesial lobe apex with 2 serrate setae. Maxilla mesial lobe mesial margin with 5 serrate setae. Maxilliped basis length 2.6 width, width 1.0 endite width; endite mesiodistal margin with 5 serrate setae, distal margin with 5 fan setae; palp article 2 length 0.8 basis width; epipod length 3.4 width, width 1.2 basis width, apex acute, mesial margin with 4 regularly spaced setae. 
Pereopod 1 basis length 2.5 width, submarginal mesial ridge with regularly spaced setae along length. Ischium length 1.6 width; inferodistal margin with 3 short setae; superodistal margin produced, acute, densely covered with long setae; mediodistal margin with 3 long setae. Merus angular, length 0.7 width, length 1.1 carpus length; inferior margin densely covered with setae; inferodistal margin not produced; superodistal margin slightly produced, apex acute, densely covered with long setae. Carpus length 0.7 width; distal margin sinuous, without short setae; carpal process long, length 3.8 width, extending greater than two-thirds but not to propodal palm articulation, straight, spatulate; inferior margin smooth, straight, densely setose, with several rows of setae; superior margin concave with mesial submarginal extension, densely setose on extension. Propodus inferior half of article flattened, length 4.4 width; inferior margin length 0.7 superior margin length, lightly setose, regularly spaced setae restricted to distal half of margin; superior margin setae absent, superior mesial surface densely covered with long, bidenticulate setae; propodal palm with 5-6 medial teeth, row of long setae, row of short setae on each side of margin, cluster of setae at inflection, terminal end with short spine. Dactylus 4.3 times as long as basal width, length 1.0 propodal palm length, curved, distal margin setose, setae regularly spaced in clusters along entire length, opposing margin with regularly spaced rows of setae and serrate setae, mesial surface lightly setose. Pereopod 2 basis medial inferior margin with stiff seta absent, anterosuperior margin with 1 penicillate seta; ischium superior margin apex with 1 stiff seta; merus superodistal apex with 1 stiff seta, inferodistal margin with 2 long setae; carpus superodistal margin with 2 short and long setae, 1 penicillate seta, inferior margin with 4 flagellated RS, inferodistal margin with $1 \mathrm{RS}$, and 3 setae; propodus superior margin with regularly spaced setae, superodistal margin with 1 penicillate seta, 1 long seta, inferior margin with 4 flagellated RS. Pereopod 7 basis superior margin with 2 penicillate setae, inferior margin with 1 stiff seta; carpus inferior margin with 1 flagellated RS, propodus inferior margin with 3 flagellated RS.

Pleopod 1 protopod length 0.8 width, lateral margins with 1 seta, posterior lobes with pair of RS, surface setae absent; rami lateral margins with regular setae along distal half of margin, apex without clustering of setae, ventral surface without setae. Pleopod 2 protopod length 2.8 width; lateral margin with 1-2 setae; endopod proximal segment length 0.5 protopod length, without setae; appendix masculina length 1.4 endopod proximal length, 0.7 protopod length, lateral margin without distal groove, apex concave, depression fringed with setae, interior pocket with fine setae, 5 anteriorly projecting distolateral spines, mesial margin without setae. Pleopod 3 endopod apex with 4 plumose setae. Pleopod 4 exopod apex with 7 plumose setae.

Uropods length 0.5 pleotelson length.

Female. Pereopod 1 basis length 2.2 times as long as wide, mesial submarginal ridge with regular long setae; ischium superodistal process developed, acute; merus superodistal process developed, acute; carpus inferodistal process acute; propodus 2.6 times as long as wide, with 2 rows of setae, serrate setae absent; propodal palm length 1.7 times propodus proximal width, 7 teeth along margin, row of serrate setae absent; dactylus length 5.7 width, length 1.0 propodal palm length, proximal margin with 11 denticulate setae.

Pleopod 2 length 1.4 width; lateral margins with less than two setae, anterior half of margins slightly concave; apex notched, asymmetric, a seta on each lobe; ventral surface sparsely setose.

Size. Males $4.0-4.3 \mathrm{~mm}$, females $4.0-4.2 \mathrm{~mm}$.

Coloration. Freshly collected specimens possess dark to almost solid black dorsal pigmentation patterns. Cephalon with almost solid markings extending from anterior margin, encompassing the eyes to their posterolateral apex, without a thin band along the anterior margin. The pleotelson has a solid anterior margin band and two separate posteromedial bifurcated markings, similar to that of Hansenium monodi Nordenstam 1946 as illustrated by Kensley and Schotte (2002, fig. 15A). Juveniles have a dark, transverse band across the cephalon between the eyes, appearing like a 'mask'.

Remarks. Machatrium thungku sp. nov. may be identified by the male pereopod 1 having a broad carpal blade that is widest distally and extends to just short of the palm; the process has a submarginal mesial blade, forming a $\mathrm{V}$-shaped groove into which the inferior margin of the propodus fits; the palm has four or five short teeth. Females also have a distinct carpal lobe. The particularly dark coloration of this species is distinctive.

Distribution. Day Reef, Lizard Island group, Great Barrier Reef; 10 metres.

Etymology. The Aboriginal adjective 'thungku', part of the 'sand beach' language of the Kuuku Ya'u tribe, means black, in reference to the dark coloration of this species; noun in apposition. 


\section{Machatrium wongat sp. nov.}

(Figures 15-18)

Material examined. All material from the Madang region, Papua New Guinea.

Holotype. $\widehat{O}^{\lambda}(3.8 \mathrm{~mm})$, Madang, barrier reef south of Wongat Island, $5.1411^{\circ} \mathrm{S}, 145.8267^{\circ} \mathrm{E}, 3$ May 1989 , coral rock on buttress, 21-25 m, coll. N.L. Bruce \& M. Jebb (MTQ W34001).

Paratypes. 3 (3.3; juv. 2.6, $2.7 \mathrm{~mm}$ ), 4 ( (ovig. 3.5-3.7; non-ovig 3.5, $3.6 \mathrm{~mm}$ ), same data as holotype (MTQ W34002). 3 ` (3.3-4.0 mm), ( $(3.3 \mathrm{~mm})$, Madang, Wongat Island, $5.1366^{\circ} \mathrm{S}, 145.8225^{\circ} \mathrm{E}, 25$ April 1989 , small rubble on sand, $10 \mathrm{~m}$, coll. N.L. Bruce \& M. Jebb (MTQ W34004). 3 đ (3.5; juv. 2.0, $2.4 \mathrm{~mm}$ ), 4 q (ovig. 3.0, 3.5; non-ovig 3.1, $4.0 \mathrm{~mm}$ ), Madang, outer reef south of Wongat Island, $5.1367^{\circ} \mathrm{S}, 145.8255^{\circ} \mathrm{E}, 21$ April 1989 ,

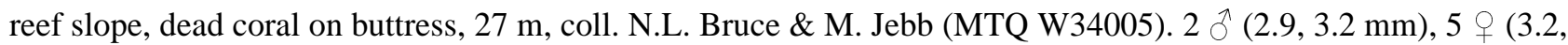
3.3, 3.6, 3.8; ovig. $3.9 \mathrm{~mm}$ ), Madang, 5.1411 ${ }^{\circ} \mathrm{S}, 145.8267^{\circ} \mathrm{E}, 3$ May 1989, 21-25 m, coll. N.L. Bruce \& M. Jebb (MTQ W34003).

Description of male. Body length 3.9 as greatest width; pereonite 1 medial width 2.5 length; pleotelson length 1.0 width.

Cephalon length 0.6 width; lateral margins acute, sparsely setose; antennal spines rounded; eyes with 14-18 ommatidia, ommatidia orange, arranged in two parallel rows.

Antennula length 0.9 cephalon width; article 1 length 1.3 width, anterolateral margin with 1 large penicillate seta; article 2 length 1.6 width, 1 penicillate seta, anterolateral margin with 1 cluster of setae, 1 penicillate seta; article 3 length 2 width, medial margin with 1 cluster of setae, anterolateral margin with 1 cluster of setae; article 4 length 0.3 width, anterior margin with 3 short setae; flagellum with 14 articles, flagellar article 1 distinctly longer than other flagellum articles, length 1.6 flagellar article 2 length.

Mandible left spine row with 4 spines, right spine row with 9 spines; palp article 1 distolateral margin with 2 long setae; article 2 with submarginal row of 7 short serrate setae. Maxillula lateral lobe apex with 9 serrate setae; mesial lobe apex with 2 serrate setae. Maxilla mesial lobe mesial margin with 7 serrate setae. Maxilliped basis length 2.4 width, width 0.95 endite width; endite mesiodistal margin with 5 serrate setae, distal margin with 5 fan setae; palp article 2 length 0.8 basis width; epipod length 3.5 width, width 1.1 basis width, apex acute, mesial margin with 7 regularly spaced setae.

Pereopod 1 basis length 3.1 width, submarginal mesial ridge with regularly spaced setae along length. Ischium length 2.0 width; inferodistal margin with 2 short setae; superodistal margin produced, acute, densely covered with long setae; mediodistal margin with 1 long seta. Merus angular, length 1.1 width, length 1.3 carpus length; inferior margin densely covered with setae; inferodistal margin not produced; superodistal margin slightly produced, apex acute, densely covered with long setae. Carpus length 1.0 width; distal margin convex, without short setae; carpal process short, length 2.2 width, extending less than halfway to propodal palm articulation, tapering, triangular; inferior margin smooth, straight, densely setose, 1 row of stiff setae, 2 rows of long serrate setae; superior margin slightly convex, densely covered with setae. Propodus inferior half of article flattened, length 5.3 width; inferior margin length 0.7 superior margin length, densely covered with rows of long and serrate setae; superior margin sparsely setose, setae regularly spaced, restricted to distal two-thirds of margin, superior mesial surface densely covered with long, bi-denticulate setae; propodal palm parallel, margin with 3 medial teeth, row of long setae, row of short setae on each side of margin, cluster of setae at articulation, terminal end with single RS. Dactylus 3.8 times as long as basal width, length 1.1 propodal palm length, curved, distal margin setose, setae regularly spaced along entire length, opposing margin with regularly spaced rows of setae and serrate setae, mesial surface lightly setose. Pereopod 2 basis medial inferior margin with stiff seta absent, anterosuperior margin with 3 penicillate setae; ischium superior margin apex with 1 stiff seta; merus superodistal apex with 1 stiff seta, inferodistal margin with 1 long setae, 1 short seta; carpus superodistal margin with 3 short and long setae, 1 penicillate seta, inferior margin with 4 flagellated RS, inferodistal margin with 1 RS, and 3 setae; propodus superior margin with regularly spaced setae, superodistal margin with 1 penicillate seta, 2 long setae, inferior margin with 4 flagellated RS. Pereopod 7 basis superior margin with 4 penicillate setae, inferior margin with 1 stiff seta; carpus inferior margin with 1 flagellated RS, propodus inferior margin with 4 flagellated RS.

Pleopod 1 protopod length 0.9 width, lateral margins with greater than 1 seta, posterior lobes with pair of RS, surface setae absent; rami lateral margins with regular setae along distal half of margin, apex with clustered setae, ventral surface with setae. Pleopod 2 protopod length 3.1 width; lateral margin with 1-2 setae; endopod proximal 
segment length 0.6 protopod length, without setae; appendix masculina length 1.4 endopod proximal length, 0.8 protopod length, lateral margin without distal groove, apex concave, depression fringed with setae, interior pocket with fine setae, 5 anteriorly projecting distolateral spines, mesial margin without setae. Pleopod 3 endopod apex with 4 plumose setae. Pleopod 4 exopod apex with 7 plumose setae. Pleopod 5 apex with 4 plumose setae.

Uropods length 0.7 pleotelson length; protopod length 3.2 width; endopod length 1.1 protopod length, 2 latitudinal rows of sensillate setae, distal and sub-distal margins with 7 penicillate setae; exopod length 0.7 protopod length, 2 latitudinal rows of sensillate setae.

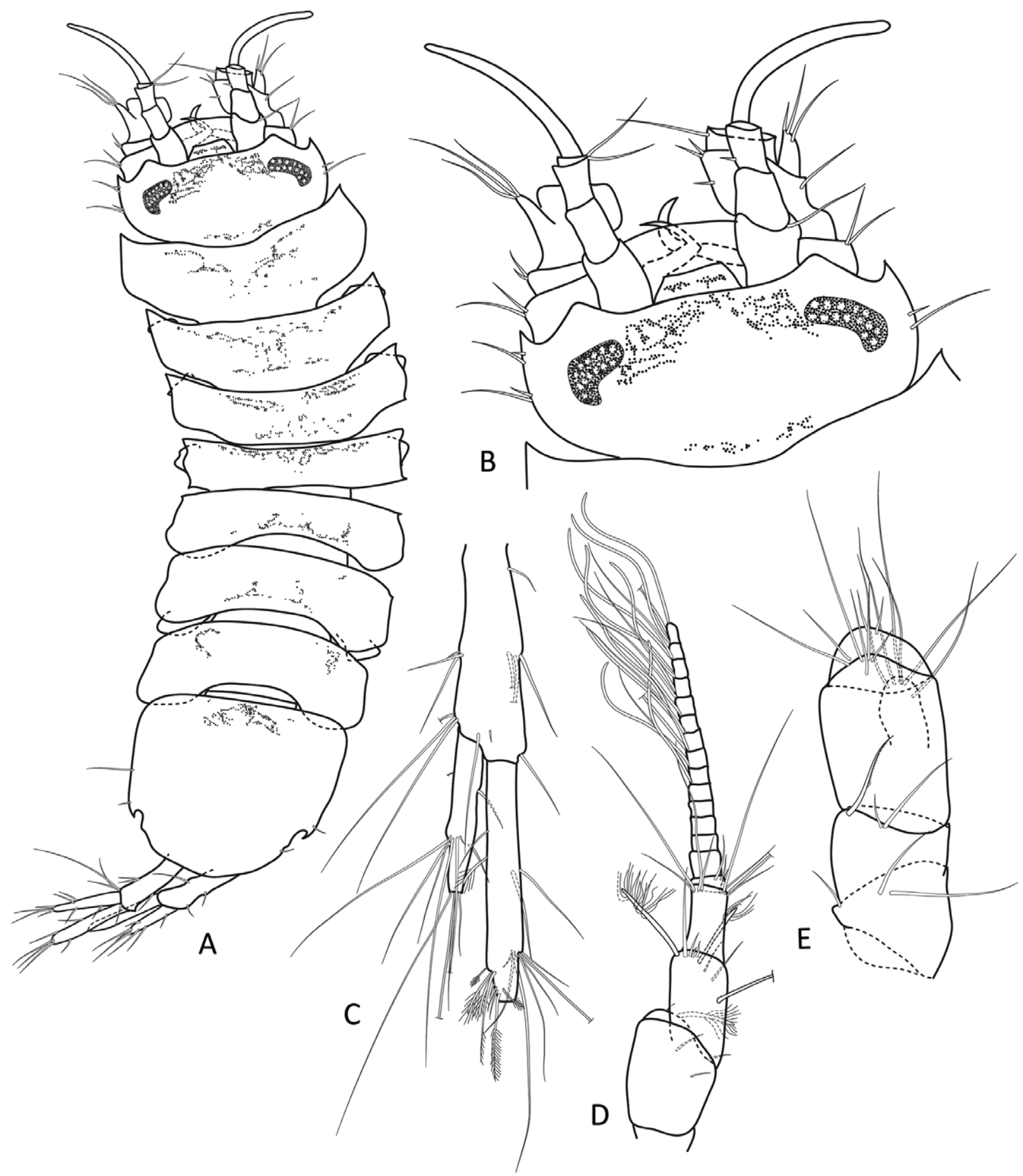

FIGURE 15. Machatrium wongat sp. nov. A, B, male holotype (MTQ W34001). A, dorsal view; B, dorsal view of cephalon; C-E, male paratype (MTQ W34002); C, uropod; D, right antennula; E, right antenna articles. 


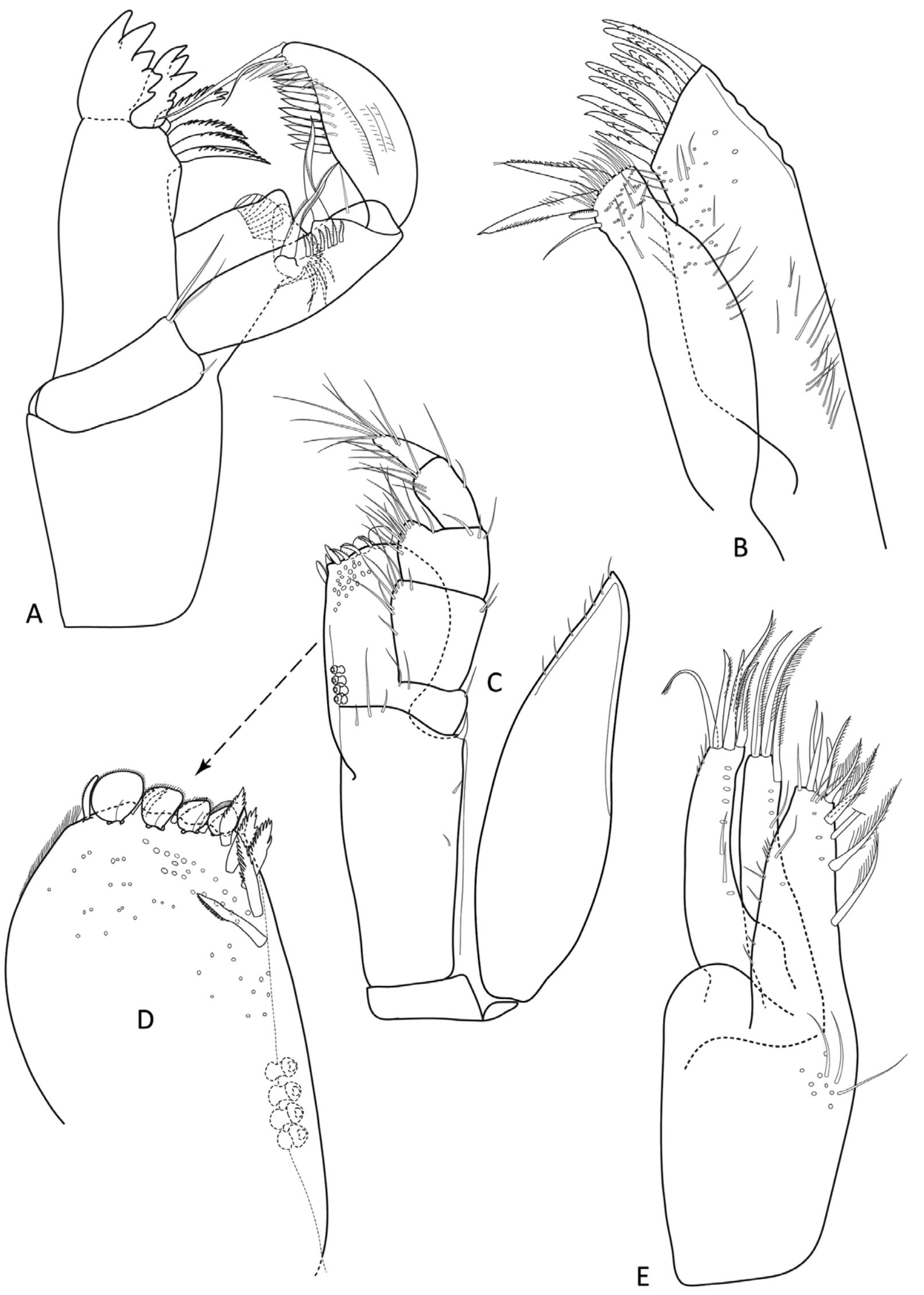

FIGURE 16. Machatrium wongat sp. nov. All male paratype (MTQ W34002). A, left mandible; B, left maxillula; C, right maxilliped; D, detail of maxilliped endite; E, left maxilla. 


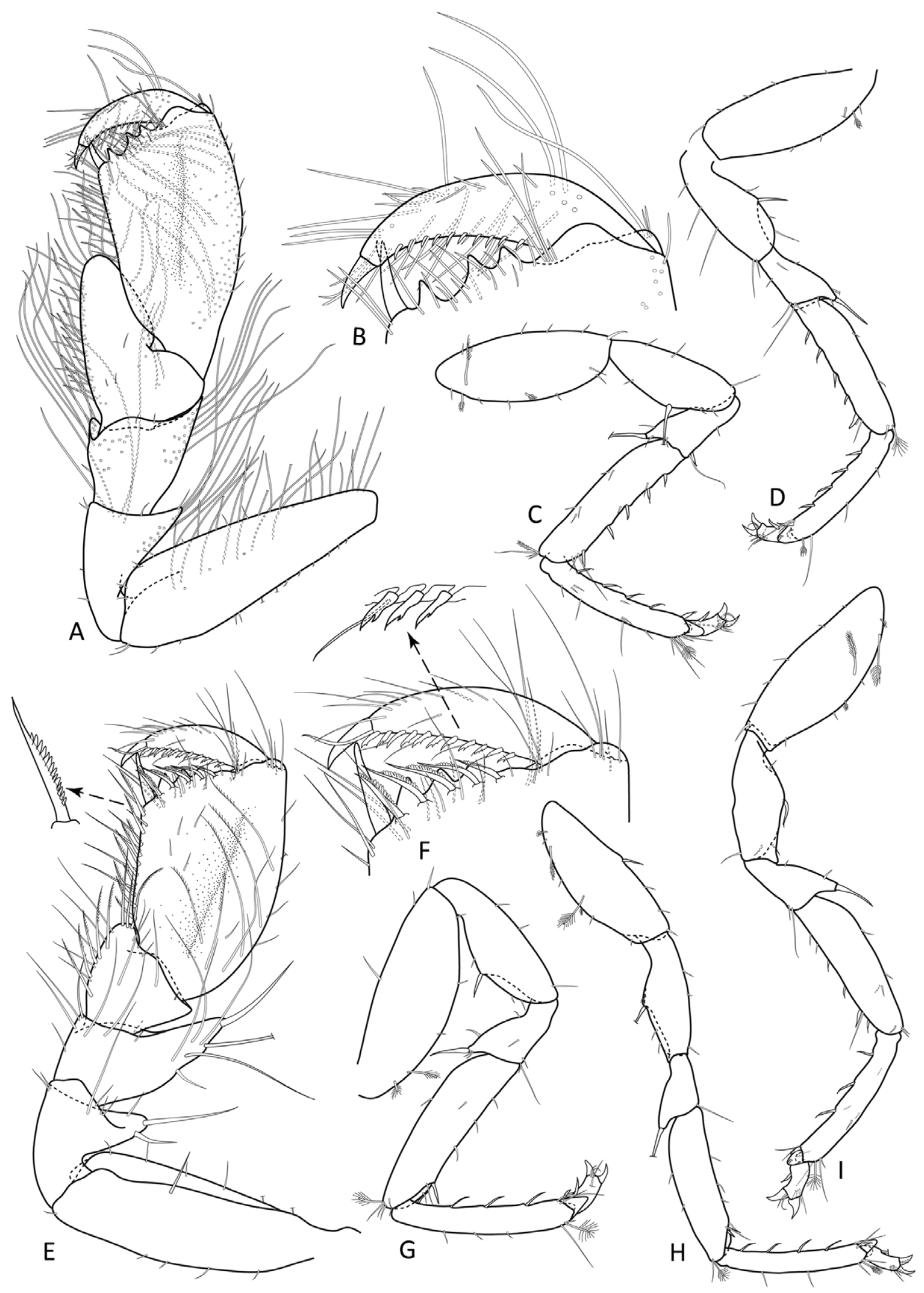

FIGURE 17. Machatrium wongat sp. nov. A, B, male holotype (MTQ W34001). A, pereopod 1; B, enlargement of dactylus, pereopod 1; C, male paratype (MTQ W34002), pereopod 2; D-G, female paratype (MTQ W34002): D, pereopod 2; E, pereopod 1; F, enlargement of dactylus, pereopod 1; G, pereopod 7; H, I, male paratype (MTQ W34002); H, pereopod 7; I, pereopod 6. 

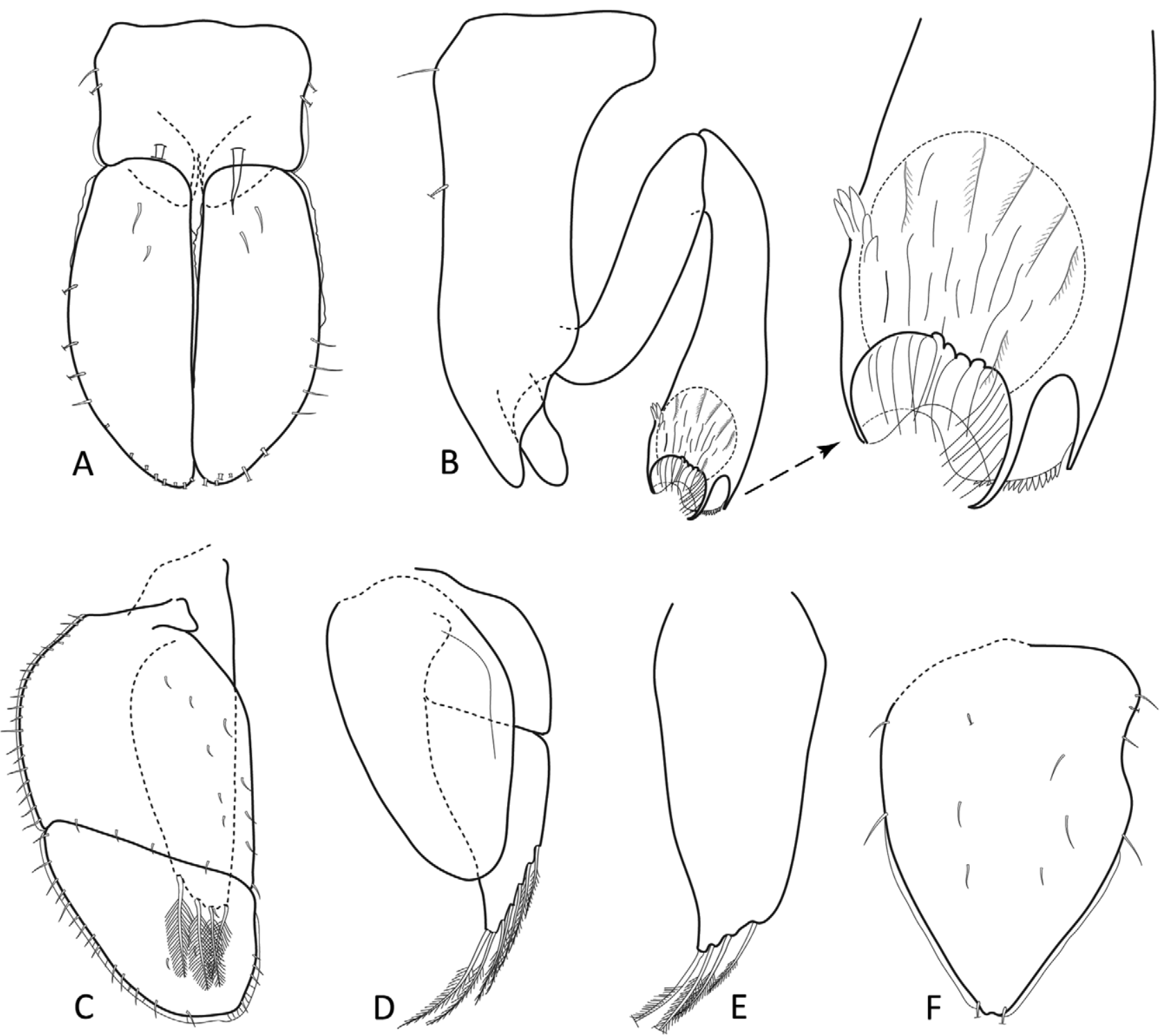

FIGURE 18. Machatrium wongat sp. nov. A-E, male paratype (MTQ W34002). A, pleopod 1; B, pleopod 2, with detail of appendix masculina apex; C, pleopod 3; D, pleopod 4; E, pleopod 5; F, female paratype (MTQ W34002), pleopod 2.

Female. Pereopod 1 basis length 3.0 times as long as wide, mesial submarginal ridge with regular short setae; ischium superodistal process developed, acute; merus superodistal process developed, acute; carpus inferodistal process rounded; propodus 3.1 times as long as wide, with one row of setae and one row of serrate setae; propodal palm length 1.6 times propodus proximal width, 4 teeth along margin, row of serrate setae present; dactylus length 3.4 width, length 1.0 propodal palm length, proximal margin with 11 denticulate setae.

Pleopod 2 length 1.5 width; lateral margins with 2-5 setae; apex notched, asymmetric, a seta on each lobe; ventral surface sparsely setose.

Size. Males 3.3-4.0 mm (mean 3.61, $\mathrm{n}=8$ ), females ovig. 3.0-3.7 (mean 3.46, $\mathrm{n}=5$ ).

Coloration. Cephalon with two small spots mesial to eyes, not adjoining, slightly posterior to anterior margin; pseudorostrum and dorsal surface of clypeus with pigmentation. Slight spotted pattern of pigmentation on all pereonites. Pleotelson with light reticulate pattern on anterior margin.

Distribution. Outer reef slopes at Madang, Papua New Guinea; at depths of 4 to 27 metres.

Remarks. Machatrium wongat sp. nov. can be identified by the male pereopod 1 having a relatively short and broadly sub-triangular carpal process and the propodal palm having three teeth.

Etymology. Named after Wongat Island, the type locality; noun in apposition. 
Machatrium tropex (Bolstad and Kensley, 1999), comb. nov.

(Figures, 19, 20)

Hansenium tropex Bolstad and Kensley, 1999:165, fig. 1-2.

Material examined. $\delta^{\widehat{N}}$ (4.0; juv. 2.5, $2.4 \mathrm{~mm}$ ), 2 ㅇ, (ovig. 3.4, $3.1 \mathrm{~mm}$ ), Madang, Papua New Guinea, barrier reef south of Wongat Island, $5.1411^{\circ} \mathrm{S}, 145.8267^{\circ} \mathrm{E}, 3$ May 1989 , coral rock on buttress, $21-25 \mathrm{~m}$, coll. N.L. Bruce \& M. Jebb (MTQ W34006).

Description of male. Body length 4.1 as greatest width; pereonite 1 medial width 2.6 length; pleotelson length 1.0 width.

Cephalon length 0.6 width; lateral margins acute, sparsely setose; antennal spines acute; eyes with 12-18 ommatidia, ommatidia orange, arranged in two parallel rows.

Antennula length 0.8 cephalon width; article 1 length 1.5 width; article 2 length 1.8 width; article 3 length 1.9 width; article 4 length 0.2 width; flagellum with 13 articles.

Mandible left spine row with 4 spines; palp article 1 distolateral margin with 2 long setae; article 2 with submarginal row of 6 short serrate setae. Maxillula lateral lobe apex with 9 serrate setae; mesial lobe apex with 2 serrate setae. Maxilla mesial lobe mesial margin with 5 serrate setae. Maxilliped basis length 2.5 width, width 1.0 endite width; endite mesiodistal margin with 4 serrate setae, distal margin with 5 fan setae; palp article 2 length 0.9 basis width; epipod length 3.7 width, width 1.0 basis width, apex acute, mesial margin with 7 regularly spaced setae.

Pereopod 1 basis length 3.5 width, submarginal mesial ridge with regularly spaced setae along length. Ischium length 1.8 width; superodistal margin not produced, concave, densely covered with long setae; mediodistal margin with 2 long setae. Merus angular, length 0.7 width, length 0.9 carpus length; inferior margin densely covered with setae; inferodistal margin not produced; superodistal margin slightly produced, apex acute, densely covered with long setae. Carpus length 1.0 width; distal margin convex, without short setae; carpal process long, length 3.8 width, extending two thirds to propodal palm articulation, straight, spatulate; inferior margin smooth, straight, densely setose, 1 row of stiff setae, 2 rows of long serrate setae; superior margin slightly convex, densely covered with setae. Propodus inferior half of article flattened, length 3.5 width; inferior margin length 0.7 superior margin length, densely covered with rows of long and serrate setae; superior margin sparsely setose, setae regularly spaced, restricted to distal half of margin, superior mesial surface densely covered with long, bi-denticulate setae; propodal palm parallel, margin with 2 medial teeth, row of long setae, row of short setae on each side of margin, cluster of setae at articulation, terminal end with single RS. Dactylus 3.7 times as long as basal width, length 1.0 propodal palm length, curved or robust, distal margin setose, setae regularly spaced along entire length, opposing margin with regularly spaced rows of setae and serrate setae, mesial surface lightly setose.

Pleopod 1 protopod length 0.9 width, lateral margins with 1 seta, posterior lobes without pair of RS, surface setae absent; rami lateral margins with regular setae along distal half of margin, apex with clustered setae, ventral surface with setae. Pleopod 2 protopod length 3.5 width; lateral margin with 1-2 setae; endopod proximal segment length 0.5 protopod length, without setae; appendix masculina length 1.5 endopod proximal length, 0.8 protopod length, lateral margin without distal groove, apex concave, depression fringed with setae, interior pocket with setae present, 3 anteriorly projecting distolateral spines, 3 clusters of short setae distal to spine, mesial margin without setae. Pleopod 3 endopod apex with 4 plumose setae. Pleopod 4 exopod apex with 7 plumose setae. Pleopod 5 apex with 4 plumose setae.

Female. Pereopod 1 basis length 3.6 times as long as wide, mesial submarginal ridge with regular short setae; ischium superodistal process developed, acute; merus superodistal process developed, acute; carpus inferodistal process rounded; propodus 3.4 times as long as wide, with one row of setae and one row of serrate setae; propodal palm length 1.6 times propodus proximal width, 4 teeth along margin, row of serrate setae present.

Pleopod 2 length 1.9 width; lateral margins with 2-5 setae, anterior half of margins straight and tapering; apex pointed, a seta on each lobe; ventral surface sparsely setose.

Size. Males 4.0 mm; females ovig. 3.1-3.4; Bolstad and Kensley (1999) recorded maximums of male at 4.8 $\mathrm{mm}$ and female ovig. at $5.0 \mathrm{~mm}$.

Coloration. This species has little pigmentation. The cephalon has a faint pigment band across the cephalon anterior margin extending to the eyes and partially circling the eye lateral margin. The pereonites have a few pinpoint spots of pigmentation and the pleotelson is without colour. 

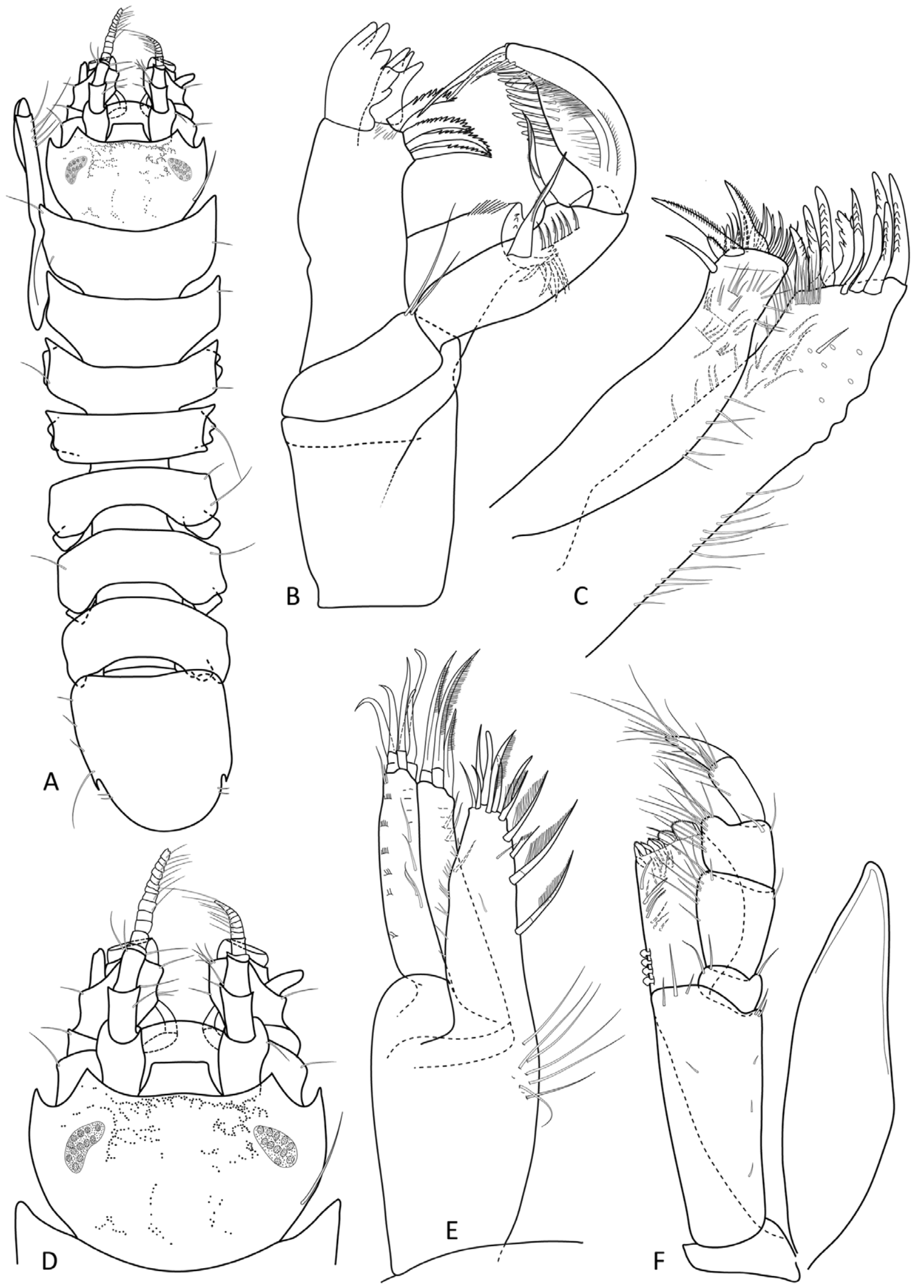

FIGURE 19. Hansenium tropex comb. nov. All male (MTQ W34002). A, male dorsal view; B, C, male: B, left mandible; C, left maxillula; D, dorsal view of cephalon; E, maxilla; F, left maxilliped. 


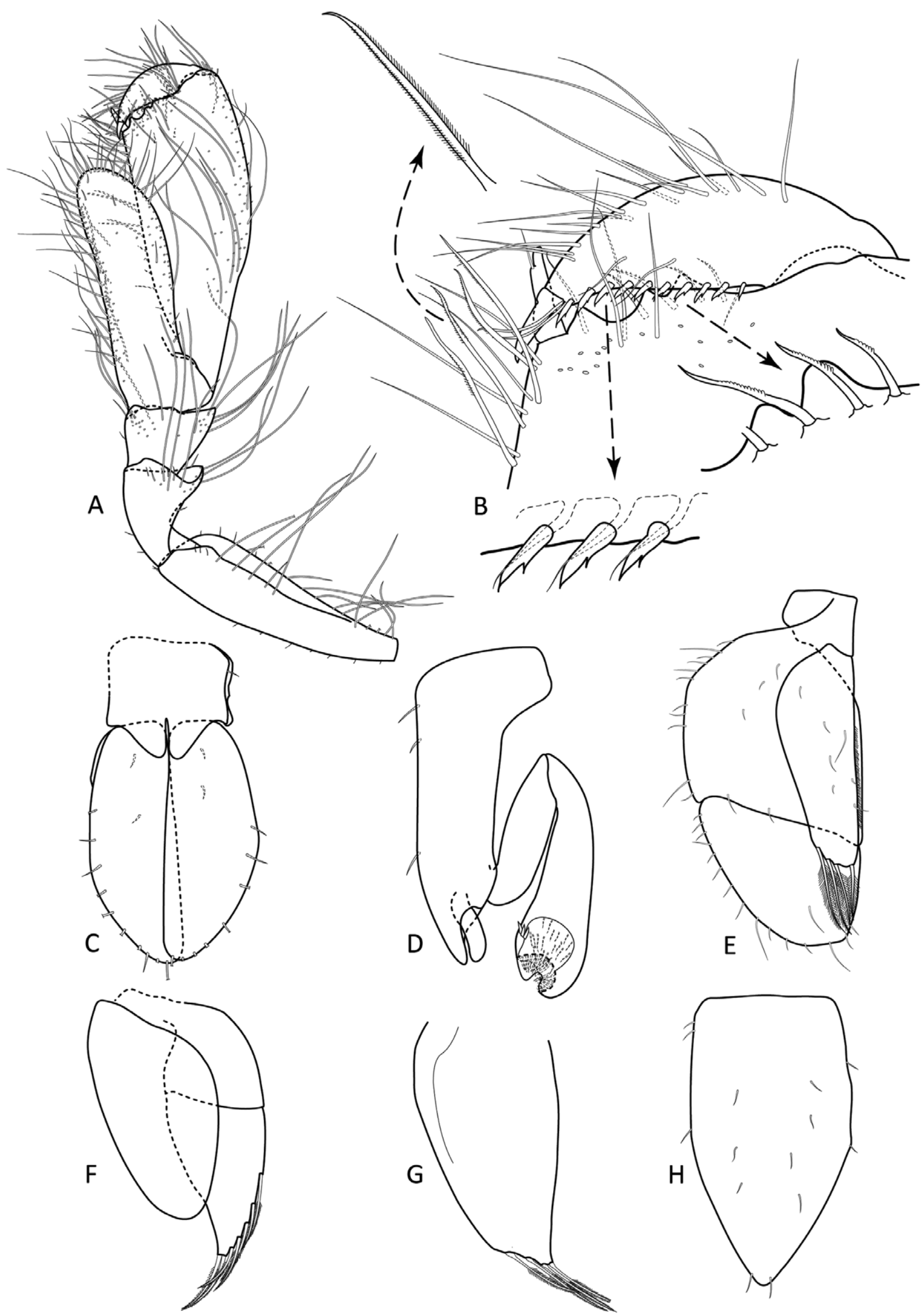

FIGURE 20. Hansenium tropex comb. nov. All male except (MTQ W34002). A-G, male; A, pereopod 1; B, enlargement of dactylus, pereopod 1; C, pleopod 1; D, pleopod 2; E, pleopod 3; F, pleopod 4; G, pleopod 5; H, female pleopod 2. 
Remarks. Machatrium tropex is characterised by the male pereopod 1 having a spatulate carpal blade with straight margins that extend nearly the entire length of the propodal inferior margin; the propodus is elongate, 3.5 times as long as wide, and the palm has two teeth. The female pleopod 2 (Fig 20F) differs slightly to that figured by Bolstad and Kensley's (2002, fig. 1F) in terms of setation.

Distribution. Madang, Papua New Guinea; at depths of 3 to 4 metres.

\section{Acknowledgements}

The authors gratefully acknowledge Australian Biological Resources Study for providing support to NLB for this study (ABRS grant 2009-30). Material was collected under the auspices of the CReefs project organised by the Australian Institute of Marine Science (AIMS), Townsville. The CReefs Australia Project was generously sponsored by BHP Billiton in partnership with The Great Barrier Reef Foundation, the Australian Institute of Marine Science and the Alfred P. Sloan Foundation; CReefs is a field program of the Census of Marine Life. The authors thank Julian Caley and Shawn Smith (AIMS) for their excellent organisation and field support; Magda Błażewicz-Paszkowycz (University of Lodz, Poland) and Kareen Schnabel (NIWA, Wellington, New Zealand), Slava Ivanenko (Moscow State University, Russia), and James Reimer (University of the Ryukyus, Japan) for their excellent help while collecting at Lizard and Heron Islands. We thank Dr Michael Türkay and Ms Kristin Petraeus (Forschungsinstitut Senckenberg, Frankfurt) for essential loans of Hans-Georg Müller's material and of type specimens; and we thank Dr M. Vannini, Dr Elena Gavetti and Ms Rita Basile (Museo Regionale di Scienze Naturali, Sezione di Zoologia, Torino, Italy) for assistance in trying to locate Nobili's isopod type specimens. The authors particularly thank Dr Robyn Cumming (MTQ) for her excellent artwork.

\section{References}

Bolstad, K.S. \& Kensley, B. (1999) Two new species of Hansenium (Crustacea: Isopoda: Asellota) from Madang, Papua New Guinea. Proceedings of the Biological Society of Washington, 112, 164-174.

Bruce, N.L. (2009) The marine fauna of New Zealand: Isopoda, Aegidae (Crustacea). NIWA Biodiversity Memoir, 122, 1-252.

Coleman, C.O., Lowry, J.K. \& MacFarlane, T. (2010) DELTA for Beginners: An introduction into the taxonomy software package DELTA. Zookeys, 1-75.

Dallwitz, M.J., Paine, T.A. \& Zurcher, E.J. (2000) User's guide to the DELTA system. A general system for processing taxonomic descriptions (4.12 ed.). CSIRO Division of Entomology, Canberra, $115 \mathrm{pp}$.

Garm, A. (2004) Revising the definition of the crustacean seta and setal classification systems based on examinations of the mouthpart setae of seven species of decapods. Zoological Journal of the Linnean Society, 2004, 233-252. http://dx.doi.org/10.1111/j.1096-3642.2004.00132.x

Hansen, H.J. (1905) On the morphology and classification of the Asellota group of Crustaceans with descriptions of the genus Stenetrium Haswell and its species. Proceedings of the Zoological Society of London, 1904, 302-331. http://dx.doi.org/10.1111/j.1469-7998.1905.tb08340.x

Haswell, W.A. (1881) On some new Australian marine Isopoda. Part I. Proceedings of the Linnean Society of New South Wales, 5, 470-481, pls 416-419.

Kensley, B. (1980) Decapod and isopod crustaceans from the west coast of Southern Africa, including Seamounts Vema and Tripp. Annals of the South African Museum, 83 (2), 13-32.

Kensley, B. (1984) The Atlantic barrier reef ecosystem at Carrie Bow Cay, Belize, III: new marine Isopoda. Smithsonian Contributions to the Marine Sciences, 24, 1-81. http://dx.doi.org/10.5479/si.01960768.24.1

Kensley, B. \& Heard, R.W. (1991) Studies on the Crustacea of the Turks and Caicos Islands, British West Indies. I. Four new marine isopod crustaceans from the vicinity of Pine Cay. Gulf Research Reports, 8, 237-246.

Kensley, B. \& Schotte, M. (2002) New species and records of Asellota from the Indian Ocean (Crustacea: Peracarida: Isopoda). Journal of Natural History, 36, 1421-1461. http://dx.doi.org/10.1080/00222930110050401

Martin, J.W., Heard, R.W. \& Wetzer, R. (2003) A new species of Stenetrium Haswell, 1881 (Crustacea: Peracarida: Isopoda: Asellota), from Navassa Island, northern Caribbean sea. Proceedings of the Biological Society of Washington, 116, 967977.

Menzies, R.J. \& Kruczynski, W.L. (1983) Isopod Crustacea (exclusive of Epicaridea). Memoirs of the Hourglass Cruises, 6, 1126. 
Miller, M.A. (1941) The isopod Crustacea of the Hawaiian Islands, II. Asellota. Occasional Papers of the Bishop Museum, 16, 305-320.

Monod, T. (1933) Mission Robert Ph. Dollfus en Égypte. Tanaidacea et Isopoda. Mémoirs Institute Égypte, 21, $161-264$.

Müller, H.-G. (1991a) The marine isopod family Stenetriidae from the coral reefs at Bora Bora and Moorea, Society Islands, with descriptions of four new species (Crustacea). Revue suisse de Zoologie, 98, 51-76.

Müller, H.-G. (1991b) Stenetriidae from coral reefs at Réunion Island, southern Indian Ocean. Description of three new species (Crustacea: Isopoda: Asellota). Senckenbergiana Biologia, 71, 303-318.

Nicholls, G.E. (1929) Some new species of Stenetrium from Western Australia. Proceedings of the Linnean Society of New South Wales, 54, 361-374.

Nierstrasz, H.F. (1941) Isopoda Genuina. III. Gnathiidea, Anthuridea, Valvifera, Asellota, Phreatoicidea. In: M. Weber \& L.F. De Beaufort (Eds.), Die Isopoden der Siboga-Expedition. E.J. Brill, Leiden, pp. 235-308.

Nobili, G. (1906) Diagnoses préliminaires de crustacés, décapodes et isopodes nouveaux recueillis par M. le Dr. G. Seurat aux Îles Touamotou. Bulletin du Muséum National d'Histoire Naturelle, le série, 12, 256-270.

Nobili, G. (1907) Richerche sui Crostacei della Polinesia. Decapodi, Stomatapodi, Anisopodi e Isopodi. Memoirie della Reale Accademia delle Scienze di Torino, 57, 351-430 + pls. 351-353.

Nordenstam, ̊̊. (1946) Marine Isopoda from Professor Dr. Sixten Bock's Expedition 1917-1918. Arkiv för Zoologi, 37A, 1-31.

Poore, G.C.B. \& Lew Ton, H.M. (2002) Suborder Asellota Latreille, 1802. In: Poore, G.C.B. (Ed.), Crustacea: Malacostraca: Syncarida and Peracarida: Isopoda, Tanaidacea, Mictacea, Thermosbaenacea, Spelaeogriphacea. Melbourne, CSIRO Publishing, pp. 32-61.

Richardson, H. (1902) The marine and terrestrial isopods of the Bermudas with descriptions of new genera and species. Transactions of the Connecticut Academy of Arts and Sciences, New Haven, 11, 277-310.

Sars, G.O. (1897) Isopoda. In: Part V, VI. Idotheidae, Arcturidae, Asellidae, Ianiridae, Munnidae. Bergen Museum, Bergen, Norway, pp. 81-116.

Schotte, M., Boyko, C.B, Bruce, N.L., Poore, G.C.B., Taiti, S. \& Wilson, G.D.F. (Eds.) (2011). World List of Marine Freshwater and Terrestrial Isopod Crustaceans. Available from: http://www.marinespecies.org/isopoda (Accessed 2 April 2011)

Schultz, G.A. (1982) Species of Protallocoxoidea and Stenetrioidea (Isopoda, Asellota) from Antarctic and southern seas. Biology of the Antarctic Seas, 32, 17-62.

Serov, P.A. \& Wilson, G.D.F. (1995) A review of the Stenetriidae (Crustacea: Isopoda: Asellota). Records of the Australian Museum, 47, 39-82. http://dx.doi.org/10.3853/j.0067-1975.47.1995.2

Serov, P.A. \& Wilson, G.D.F. (1999) A revision of the Pseudojaniridae Wilson, with a description of a new genus of Stenetriidae Hansen (Crustacea: Isopoda: Asellota). Invertebrate Taxonomy, 13, 67-116. http://dx.doi.org/10.1071/IT96038

Stebbing, T.R.R. (1905) Report on the Isopoda collected by Professor Herdman, at Ceylon, in 1902. Report to the Government of Ceylon on the Pearl Oyster Fisheries of the Gulf of Manaar, 1905, Supplementary Report, 4, 47-64.

Watling, L. (1989) A classification system for crustacean setae based on the homology concept. In: Felgenhauer, B.E., Watling, L. \& Thistle, A.B. (Eds.) Functional morphology of feeding and grooming in Crustacea. A.A. Balkema, Rotterdam, pp. $15-26$. 